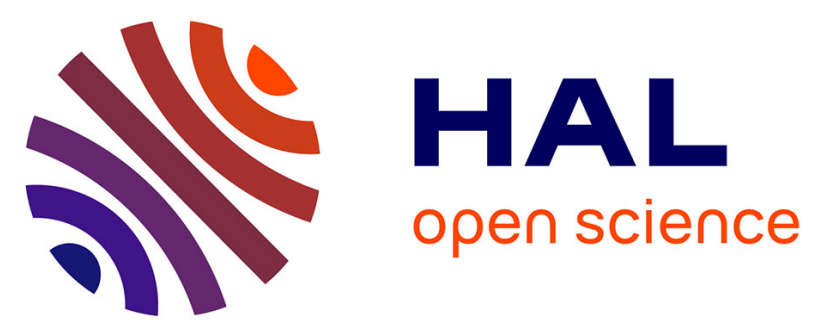

\title{
Holocene climate variability of the Western Mediterranean: Surface water dynamics inferred from calcareous plankton assemblages
}

\author{
Pietro Bazzicalupo, Patrizia Maiorano, Angela Girone, Maria Marino, \\ Nathalie Combourieu-Nebout, Nicola Pelosi, Emília Salgueiro, Alessandro \\ Incarbona
}

\section{To cite this version:}

Pietro Bazzicalupo, Patrizia Maiorano, Angela Girone, Maria Marino, Nathalie CombourieuNebout, et al.. Holocene climate variability of the Western Mediterranean: Surface water dynamics inferred from calcareous plankton assemblages. The Holocene, 2020, 30 (5), pp.691-708. 10.1177/0959683619895580 . hal-02437889

\section{HAL Id: hal-02437889 \\ https://hal.science/hal-02437889}

Submitted on 20 Nov 2020

HAL is a multi-disciplinary open access archive for the deposit and dissemination of scientific research documents, whether they are published or not. The documents may come from teaching and research institutions in France or abroad, or from public or private research centers.
L'archive ouverte pluridisciplinaire HAL, est destinée au dépôt et à la diffusion de documents scientifiques de niveau recherche, publiés ou non, émanant des établissements d'enseignement et de recherche français ou étrangers, des laboratoires publics ou privés. 
1 Holocene climate variability of the western Mediterranean: surface water dynamics inferred from calcareous plankton assemblages

3

Pietro Bazzicalupo $^{1}$, Patrizia Maiorano ${ }^{1}$, Angela Girone ${ }^{1}$, Maria Marino ${ }^{1}$, Nathalie CombourieuNebout $^{2}$, Nicola Pelosi $^{3}$, Emília Salgueiro $^{4,5}$, Alessandro Incarbona $^{6}$

1 Dipartimento di Scienze della Terra e Geoambientali, Università degli Studi di Bari Aldo Moro, via E. Orabona 4, 70125, Bari, Italy

2 French National Centre for Scientific Research UMR 7194 - Histoire Naturelle de l'Homme Préhistorique, Paris, France

3 Istituto di Scienze Marine (ISMAR) - Consiglio Nazionale delle Ricerche, Calata Porta di Massa, 80133Napoli, Italy

4 Div. Geologia e Georecursos Marinhos, Instituto Português do Mar e da Atmosfera (IPMA), Lisbon, 1749077, Portugal 5 Centre of Marine Sciences, Universidade do Algarve, Faro, 8005-139, Portugal. 6 Università di Palermo, Dipartimento di Scienze della Terra e del Mare, Via Archirafi 22, 90134 Palermo, Italy

\section{Keywords}

Coccolithophores, Foraminifera, Alboran Sea, Holocene, Paleoclimate, Paleoproductivity, Millennial-centennial scale climate variability

\section{.}

\section{Abstract}

A high resolution study (centennial-scale) has been performed on the calcareous plankton assemblage of the Holocene portion of the Ocean Drilling Program Site 976 (Alboran Sea) with the aim to identify main changes in surface water dynamic. The dataset also provided a Seasonal foraminiferal Sea Surface Water Temperatures (SSTs), estimated using the modern analog technique SIMMAX 28, and it was compared with available geochemical and pollen data at the site.

Three main climate shifts were identified: I) The increase in abundance of Syracosphaera spp. and Turborotalita quinqueloba marks the early Holocene humid phase, during maximum summer insolation and enhanced river runoff. It is concomitant with the expansion of Quercus, supporting high humidity on land. It ends at $8.2 \mathrm{ka}$, registering a sudden temperature and humidity reduction; II) The rise in the abundances of Florisphaera profunda and Globorotalia inflata, at ca. $8 \mathrm{ka}$, indicates the development of the modern geostrophic front, gyre circulation and of a deep nutricline following the sea-level rise; III) The increase of small Gephyrocapsa and Globigerina bulloides at $5.3 \mathrm{ka}$, 
suggests enhanced nutrient availability in surface waters, related to more persistent wind-induced upwelling conditions. Relatively higher winter SST in the last $3.5 \mathrm{kyr}$ favored the increase of Trilobatus sacculifer, likely connected to more stable surface water conditions. Over the main trends, a short term cyclicity is registered in coccolithophore productivity during the last 8 kyr. Short periods of increased productivity are in phase with Atlantic waters inflow, and more arid intervals on land. This cyclicity has been related with periods of positive North Atlantic Oscillation (NAO) circulations. Spectral analysis on coccolithophore productivity confirms the occurrence of millennial-scale cyclicity suggesting an external (i.e. solar) and an internal (i.e. atmospheric/oceanic) forcing.

\section{Introduction}

An increasing number of climate records reveals that the Holocene has experienced a pervasive millennial- and centennial-scale climate variability (e.g. Jalut et al., 2009; Magny et al., 2013; Mayewski et al., 2004; Walker et al., 2012; Wanner et al., 2015), well-documented in both the North Atlantic (e.g. Bond et al., 2001; Repschläger et al., 2017; Thornalley et al., 2009) and western Mediterranean (e.g. Ausín et al., 2015a; Cacho et al., 2001; Català et al., 2018; Frigola et al., 2007; Jalali et al., 2017, 2016; Nieto-Moreno et al., 2015; Rodrigo-Gámiz et al., 2011). The western Mediterranean Sea is in fact extremely sensitive to the changes experienced in the North Atlantic and is an ideal location for high-frequency climatic investigations, because water mass properties changes and oceanographic and atmospheric circulation oscillations are usually amplified (Cacho et al., 1999, 2001; Català et al., 2018; Frigola et al., 2007, 2008; Jalali et al., 2016; Moreno et al., 2002; NietoMoreno et al., 2015; Sierro et al., 2005; Toucanne et al., 2012). The millennial-scale climate variability in the western Mediterranean is reflected in different water column configurations and oceanographic features (e.g. fronts and eddies) that left a clear signature in the calcareous plankton assemblages (Ausín et al., 2015a; Pérez-Folgado et al., 2003, 2004; Sbaffi et al., 2001). During the Holocene, the Alboran Sea experienced relevant oceanographic perturbations, the most important of which was the instauration of the modern geostrophic front and establishment of gyre anticyclonic circulation dynamics, following sea level rising after the last deglaciation (Ausín et al., 2015b; Català et al., 2018; Colmenero-Hidalgo et al., 2004; Heburn and La Violette, 1990; Rohling et al., 1995; Weaver and Pujol, 1988). This important change also marked the end of the Organic Rich Layer 1 (ORL1) deposition in the western Mediterranean (Bárcena et al., 2001; Cacho et al., 2002; JimenezEspejo et al., 2007, 2008; Rogerson et al., 2008). Targeting the high frequency oscillations experienced during the Holocene, a growing attention has been focused on the impact of the North Atlantic Oscillation (NAO) atmospheric pattern in the western Mediterranean Sea, in terms of westerlies strength and deep water production, precipitation and river runoff, and coccolithophore 
productivity (Ausín et al., 2015a; Fletcher et al., 2012; Frigola et al., 2007; Jalali et al., 2016; Moreno et al., 2005; Smith et al., 2016; Trigo et al., 2004; Zielhofer et al., 2017). However, only a few studies so far have documented the relationship between coccolithophore productivity and atmospheric variability, like the present NAO index (e.g. Ausín et al., 2015a).

In this framework we carried out, over the last $12 \mathrm{ka}$, at the Ocean Drilling Program (ODP) Site 976, an integrated study between coccolithophores and planktonic foraminifera by a centennial-scale resolution, not available so far in the Alboran Sea. The aim was to reconstruct paleoenvironmental fluctuations in the Alboran Sea and to discuss the mechanisms controlling fossil assemblage and productivity variations at different time scales. A planktonic foraminifera-based Sea Surface Temperature (SST) reconstruction is also provided, to have further insights on seasonal and annual temperature variations. In addition, spectral and wavelet analyses of the coccolithophore accumulation rates are performed to identify the different periodicities of coccolithophore productivity fluctuations. The study also benefits from the comparison with additional inorganic and organic geochemical proxies (Jiménez-Amat and Zahn, 2015; Martrat et al., 2014) and pollen data (Combourieu-Nebout et al., 2009) available at the same site, improving the paleoclimate reconstruction through a direct multi-proxy approach.

\section{Area of Study}

\section{Present hydrographical conditions}

The ODP Site 976 was recovered off the Spanish coast in the Alboran Sea, the westernmost basin of the Mediterranean Sea, bordering the Atlantic Ocean (Fig. 1). Surrounding lands include the high physiography of the Betic cordillera and Moroccan Rif mountains, that might provide a certain riverine input, although subjected to high seasonality and extreme climatic events (Jimenez-Espejo et al., 2008; Liquete et al., 2005; Lobo et al., 2006). Surface Atlantic Water (AW) pours inside the Alboran basin through the Strait of Gibraltar, as a constant stream of surface low-salinity waters called the Atlantic Jet (AJ). The latter contributes to the creation of two quasi-permanent meso-scale anticyclonic gyres: the Western Anticyclonic Gyre (WAG) and the Eastern Anticyclonic Gyre (EAG) (Fig. 1) (Heburn and La Violette, 1990; Sarhan et al., 2000). In the area, two mechanisms are known to be relevant for the upwelling dynamic: the southward drifting of the AJ, that would allow the water from below to rise, and the wind stress (Sarhan et al., 2000). The influence of the vertical mixing of AJ and deeper Mediterranean waters, concurrently with the complex bottom topography, forms areas of geostrophic front and quasi-permanent upwelling: the Alboran front and the Almeria-Oran front (Fig.1) (Perkins et al., 1990; Viúdez et al., 1996). 
103 The combination of gyres and upwelling fronts results in increased nutrient availability and high 104 productivity waters, among the richest within the rest of the Mediterranean (D'Ortenzio and 105 D'Alcalà, 2009; Garcia-Gorriz and Carr, 1999). Counteracting the AW inflow, the denser and more 106 saline Mediterranean waters exit the basin through the Mediterranean Outflow Water (MOW), that 107 includes the western Mediterranean Deep Water (WMDW) from the Gulf of Lion and the Levantine 108 Intermediate Water (LIW) from the far East of the Mediterranean basin (Fig. 1) (Millot, 2008; Perkins 109 et al., 1990). Deep water formation is controlled by surface heat loss due to winds blowing from the 110 north and north-west (Font et al., 2007; Mertens and Schott, 1998; Rixen et al., 2005; Smith et al., 111 2008).

\section{Present Climate Conditions}

114 The Alboran Sea climate conditions are under the influence of the Azores high pressure cell and its seasonal latitudinal shift, resulting in mild wet winters and dry hot summers (Lionello, 2012; Moreno et al., 2012; Rohling et al., 2015; Sumner et al., 2001). At decadal and inter-annual time scales, atmospheric variability is regulated by the North Atlantic Oscillation (NAO) index, which is characterized by positive (NAO+) and negative (NAO-) regimes (Hurrell, 1995; Olsen et al., 2012; Smith et al., 2016; Trigo et al., 2004). During a NAO+ regime, stronger pressure difference between the Azores High and Icelandic Low atmospheric cells brings storm trajectories to the north, determining stormier and wetter weather in northwest Europe and dryer winters in southern Europe and North Africa (Olsen et al., 2012; Smith et al., 2016; Zielhofer et al., 2017). At NAO- regime, weaker difference between the two pressure cells leads storm tracks to the south, enhancing precipitations over southern Europe and North Africa (Smith et al., 2016; Wanner et al., 2015). In the Iberian Peninsula, winter precipitation mode has been related to air masses raised by atmospheric instabilities and moisture supply from the tropical-subtropical North Atlantic corridor (Gimeno et al., 2010).

\section{Materials and Methods}

\section{Core material and available data sets}

131 The ODP Site 976 (Comas et al., 1996) is located about $60 \mathrm{~km}$ south of the Iberian Peninsula and about $110 \mathrm{~km}$ East of the Strait of Gibraltar $\left(36^{\circ} 12.3^{\prime} \mathrm{N}, 4^{\circ} 18.7^{\prime} \mathrm{W}\right)$ (Fig. 1). The cores were recovered on the lower part of a very gentle slope, dipping southward of the Spanish margin in the Alboran Basin, at a depth of $1108 \mathrm{~m}$. The investigated sediments are from Hole C - Core $1 \mathrm{H}-$ sections 1-3 (Comas et al., 1996), between 0.07 to $4.03 \mathrm{~m}$ below the sea floor. Main lithology is composed of nannofossil rich clay, with slight to moderate bioturbation and common shell fragments (Comas et 
al., 1996). One Organic Rich Layer (ORL) occurs in the studied interval and is identified on the basis of the maximum accumulation of di- and tri- alkenones of 37 carbons (Martrat et al., 2004, 2014). The age model used in the present study is from Martrat et al. (2014), based on available ${ }^{14} \mathrm{C}$ calibrated AMS radiocarbon dates (Combourieu-Nebout et al., 2002, 2009). Sampling resolution of calcareous plankton dataset varies between 1 sample every 2 to $6 \mathrm{~cm}$, according to the variable sedimentation rate $(20$ to $60 \mathrm{~cm})$, thus providing a temporal resolution of one sample every ca. 100 years.

\section{Calcareous plankton}

The coccolith assemblages were analyzed in 129 samples. Sample preparation for the coccolith analysis follows the random settling technique by Flores and Sierro (1997). The quantitative analyses were performed using a polarized light microscopy at 1000X magnification. The relative abundance of taxa was estimated counting at least 500 specimens per sample, in variable fields of view. Reworked calcareous nannofossils were estimated separately during this counting. The absolute abundance of taxa is expressed as Nannofossil Accumulation Rate (NAR). The total NAR, used to determine coccolithophore paleoproductivity (Baumann et al., 2004; Steinmetz, 1994), was estimated following Flores and Sierro (1997):

$$
\mathbf{N A R}=\mathbf{N} * \mathbf{w} * \mathbf{S}
$$

where $\mathbf{N}$ is the number of coccoliths per gram of sediment $\left(\mathrm{Ng}^{-1}\right)$, $\mathbf{w}$ is the wet bulk density $\left(\mathrm{g} \times \mathrm{cm}^{-3}\right)$ (shipboard bulk density data, Comas et al., 1996), and $\mathbf{S}$ is the sedimentation rate $\left(\mathrm{cm} \times \mathrm{ky}^{-1}\right)$. Wet bulk density is frequently used as a substitute to dry bulk density, in the absence of the latter, to estimate coccolithophore production (Grelaud et al., 2009; Marino et al., 2014; Stolz and Baumann, 2010). For taxonomic identification we referred to Young et al. (2003) and Jordan et al. (2004). According to Flores et al. (2000): gephyrocapsids with high angle bridge $\left(>50^{\circ}\right)$ and $>3 \mu \mathrm{m}$ in size are indicated as Gephyrocapsa oceanica; gephyrocapsids $>3 \mu \mathrm{m}$ in size with a low angle bridge $(<$ $25^{\circ}$ ) are indicated as Gephyrocapsa muellerae; small Gephyrocapsa includes gephyrocapsids $<3 \mu \mathrm{m}$ in size. Specimens of Emiliania huxleyi were differentiated into two main groups following size criteria (Colmenero-Hidalgo et al., 2002): large E. huxleyi $>4 \mu \mathrm{m}$ and small E. huxleyi $<4 \mu \mathrm{m}$. Warm water taxa are grouped according to their ecological preference for tropical-subtropical waters (Baumann et al., 2004; Boeckel and Baumann, 2004; Winter and Siesser, 1994). The group includes: Calciosolenia spp., Discosphaera tubifera, Rhabdosphaera stylifera, Rhabdosphaera clavigera, Umbilicosphaera foliosa, Umbilicosphaera sibogae, Umbellosphaera spp., Oolithotus spp.

Planktonic foraminifera assemblages were analyzed in 122 samples washed through 63 and $150 \mu \mathrm{m}$ sieves. The residues $(>150 \mu \mathrm{m})$ were split, until a representative aliquot containing about 300 specimens has been obtained. All specimens were counted in the aliquots and species abundances 
were quantified as percentages on the total number of planktonic foraminifers (relative abundance) and as absolute abundances expressed as planktonic foraminifera Accumulation Rates (pfAR). The pfAR has been calculated following Giraudeau et al. (2001):

$$
\mathbf{p f A R}=\mathbf{A A} * \mathbf{w} * \mathbf{S}
$$

where $\mathbf{A A}$ is the number of specimens per gram of dry sediment (nr/g), w is the wet bulk density $\left({\mathrm{g} \times \mathrm{cm}^{-3}}\right)$ (shipboard bulk density data, Comas et al., 1996), and $\mathbf{S}$ is the sedimentation rate $\left(\mathrm{cm} \times \mathrm{ky}^{-1}\right)$. Sixteen species or species groups were distinguished. Globigerinoides ruber includes morphotypes of G. ruber white, and Globigerinoides elongatus (sensu Aurahs et al., 2011); Trilobatus sacculifer includes Trilobatus trilobus, Trilobatus sacculifer and Trilobatus quadrilobatus (sensu André et al., 2012; Hemleben et al., 1989; Spezzaferri et al., 2015). Globoturborotalita rubescens includes Globoturborotalita tenella because of their similar ecological preference (Capotondi et al., 1999). The taxonomy of Neogloboquadrina spp. follows criteria by Darling et al., (2006): Neogloboquadrina incompta includes specimens previously referred to N. pachyderma (dextral) and intergrades between $N$. pachyderma (dextral) and N. dutertrei. Neogloboquadrina pachyderma only includes the left coiling specimens.

According to their ecological preference (Hemleben et al., 1985; Kucera et al., 2005; Pujol and Vergnaud-Grazzini, 1995) and to previous Mediterranean Sea paleoclimatic reconstructions (De Rijk et al., 1999; Rohling et al., 1997), G. ruber, T. sacculifer, Hastigerina pelagica, G. rubescens, Orbulina universa, Beella digitata and Globigerinella siphonifera have been grouped as warm water taxa.

\section{Sea Surface Temperature estimation}

Planktic foraminifera assemblages were used to reconstruct annual, summer (July to September) and winter (January to March) SST with the modern analog technique non distance-weighted SIMMAX 28 and 10 analogs (Pflaumann et al., 1996). Considering that the study site is influenced by Atlantic and Mediterranean ocean circulation, following Schirrmacher et al. (2019), we use the combined North Atlantic core-top database (Kucera et al., 2005; Salgueiro et al., 2010, 2014) and the Mediterranean database (Hayes et al., 2005), and the root mean square error of both annual and seasonal SST reconstructions is about $1.3^{\circ} \mathrm{C}$ (Schirrmacher et al., 2019).

\section{Power spectral and wavelet analysis}

Spectral and wavelet analyses were performed on the total NAR, displaying relevant high frequency oscillations throughout the record. The analysis of the non-stationary (frequency changes along time) and non-linear signals, was performed by applying the Empirical Mode Decomposition algorithm 
(EMD) of Huang et al. (1998) in order to decompose multi-component signals into a series of amplitude and frequency modulation (AM-FM) waves, each with slowly varying amplitude and phase. A major advantage of EMD is that the basis functions are derived from the signal itself, hence the analysis is adaptive, in contrast to the traditional methods where the basis functions are fixed as sine and cosine for Fourier transform like methods and the mother wavelet functions for wavelet analysis.

The signal and the Intrinsic Mode Functions (IMF) components are analysed without interpolation, keeping the original evenly sampling intervals, with:

1. "REDFIT", that computes the spectrum of a possibly unevenly sampled time-series, by using the Lomb-Scargle Fourier transform. The spectrum is bias-corrected using spectra computed from simulated AR(1) series and the theoretical AR(1) spectrum (Lomb, 1976; Scargle, 1982; Schulz and Mudelsee, 2002).

2. Foster's (1996) weighted wavelet Z-transform (WWZ). To analyze non-stationary and irregularly sampled signals, we need an extension of the classic wavelet formalism. Foster (1996), who defines the WWZ, developed such extension as a suitable weighted projection method re-orthogonalizing the three basic functions (real and imaginary part of the Morlet wavelet and a constant) by rotating the matrix of their scalar products. Furthermore, he introduces statistical F-tests to distinguish between periodic components and a noisy background signal.

\section{Results}

\section{Calcareous nannofossils}

Calcareous nannofossils are generally abundant and well preserved and dissolution phenomena seem not to be significant. Abundances of the most relevant taxa are presented in Fig. 2 and no major discrepancies are observed between relative and absolute trends. The total NAR ranges between 0.5 $\mathrm{x} 10^{11}$ coccoliths $\mathrm{x} \mathrm{cm}^{-2} \mathrm{x} \mathrm{kyr}^{-1}$ and $2 \times 10^{11}$ coccoliths $\mathrm{x} \mathrm{cm}^{-2} \mathrm{x} \mathrm{kyr}^{-1}$, with an average of $0.8 \times 10^{11}$ coccoliths $\mathrm{x} \mathrm{cm}^{-2} \mathrm{x} \mathrm{kyr}^{-1}$ (Fig. 2). A marked abundance peak occurs at about $8.2 \mathrm{ka}$, and an oscillating pattern is recorded in the last $8 \mathrm{kyr}$ (Fig. 2). Considering the relative abundances of the taxa (\%), $E$. huxleyi $<4 \mu \mathrm{m}$ represents the main taxon, having percentages between 40 and $60 \%$ and the highest values between 10 and 8 ka (Fig. 2). Among gephyrocapsids, G. muellerae results to be the most abundant in the lower part of the record, with values reaching $30 \%$ of the assemblage, followed by a descending trend (Fig. 2). Small Gephyrocapsa show an increase in abundance from 8\%, between 10 and $7 \mathrm{ka}$, to $15 \%$ from $5.3 \mathrm{ka}$ upward (Fig. 2). Gephyrocapsa oceanica, mainly represented by morphotypes larger than $5 \mu \mathrm{m}$, shows abundance fluctuations between 3 and $10 \%$ throughout the 
239 Holocene (Fig. 2). Florisphaera profunda, although not a dominant component of the assemblages 240 (with very few isolated peaks greater than 15\%), shows a distinct pattern, with very low percentage 241 values up to $\sim 8 \mathrm{ka}$, that clearly increase upwards in fluctuating abundances (Fig. 2). Among less 242 abundant taxa, Syracosphaera spp. (S. histrica and S. pulchra), having a mean value of 1\%, show a 243 distinct increase between 11 and $8 \mathrm{ka}$, reaching values of about 5\% (Fig. 2). The warm water coccolith 244 taxa have very low abundances throughout the succession, with a mean value of $2 \%$; the group shows 245 a gradual increase between 12 and $8 \mathrm{ka}$, and fluctuating pattern afterwards (Fig. 2). Helicosphaera 246 carteri and E. huxleyi $>4 \mu \mathrm{m}$ show a similar pattern with abundance values ranging between 10 and $247 \quad 15 \%$ in the lowest part of the succession (during the Younger Dryas), followed by a clear decreasing 248 trend, with values around 1\% (Fig. 2). Other taxa, not showing particular trends or significant 249 fluctuations, are represented by Coccolithus pelagicus ssp. pelagicus, Gephyrocapsa caribbeanica 250 and Coronosphaera spp., with percentages not higher than 5\%. Subordinate taxa do not exceed the $2513 \%$ of the assemblage and include Coccolithus pelagicus ssp. braarudii, Coccolithus pelagicus ssp. 252 azorinus, Braarudosphaera bigelowii, Calcidiscus leptoporus ssp. small (3-5 $\mu \mathrm{m})$, C. leptoporus ssp. 253 leptoporus $(5-8 \mu \mathrm{m}), C$. leptoporus ssp. quadriperforatus $(8-10 \mu \mathrm{m})$, Ceratolithus spp., 254 Helicosphaera pavimentum, Helicosphaera hyalina, Pontosphaera spp., Gladiolithus flabellatus, 255 Scyphosphaera spp. and Umbilicosphaera hulburtiana. Reworked taxa occur in the samples with 256 variable abundances, never exceeding about 4\% (Fig. 2).

\section{Planktonic foraminifera assemblages}

259 Planktonic foraminifera are well preserved and diversified. Relative and absolute abundances of the 260 most abundant/significant planktonic foraminifera taxa/groups show comparable trends throughout the entire succession. Neogloboquadrina incompta and Turborotalita quinqueloba are abundant in the lower part of the record (between $12.5 \mathrm{ka}$ and about $8 \mathrm{ka}$ ) and undergone a strong decreasing upward (Fig. 3). Although with lower relative and absolute abundances, G. ruber and G. bulloides are also abundant in this interval (Fig. 3). At about $8 \mathrm{ka}$, a prominent replacement of G. inflata at the expense of $N$. incompta and T. quinqueloba occurs. Starting from 8 ka upwards, G. inflata together with G. bulloides and G. ruber, became the most abundant taxon in the record (Fig. 3). Globigerinita glutinata, with relative abundances not higher than $10 \%$, doesn't show any relevant fluctuation in the distribution pattern (Fig. 3). Trilobatus sacculifer became more abundant from about 8 ka upward, showing a more prominent increase, as relative and absolute abundances, during the last $3.5 \mathrm{kyr}$ (Fig. 3). A similar distribution pattern is also shown by Truncorotalita truncatulinoides (Fig. 3). Other taxa showing a very scattered distribution in the studied interval, with relative abundances $<3 \%$ and any 
significant fluctuations, are not shown in Fig. 3. They are represented by Globorotalia scitula, Globigerina falconensis, G. rubescens, N. pachyderma, G. siphonifera and O. universa.

\section{Sea Surface Temperature}

Annual, summer and winter SST patterns show sharp fluctuations between $10.2 \mathrm{ka}$ and $8.7 \mathrm{ka}$ characterized by strong drops of winter and summer temperature values greater than $10^{\circ} \mathrm{C}$ (Fig. 3). During this interval an important increase of $T$. quinqueloba is observed, together with high occurrence of $N$. incompta and $N$. dutertrei and increasing trend of warm water foraminifera taxa (Fig. 5). In this interval, the similarity index slightly decreases (Fig. 3), indicating that this species combination is not usual in the modern oceanographic condition for the North Atlantic and the Mediterranean region. In this interval the average annual SST is about $13.9^{\circ} \mathrm{C}$, while average winter and summer temperatures are $11.7^{\circ} \mathrm{C}$ and $16.7^{\circ} \mathrm{C}$ respectively (Fig. 3). For the last $8 \mathrm{kyr}$, the average annual SST is about $18.5^{\circ} \mathrm{C}$, while winter SST in the Alboran Sea varies around ca. $15{ }^{\circ} \mathrm{C}$, in agreement with modern conditions $\left(15.4{ }^{\circ} \mathrm{C}\right.$; Locarnini et al., 2013) (Fig. 3). The average summer SST is $22.6^{\circ} \mathrm{C}$, exceeding modern ones $\left(21.4^{\circ} \mathrm{C}\right.$; Locarnini et al., 2013) (Fig. 3). Low temperatures values are recorded between about 8.6 and $7.7 \mathrm{ka}$ both in summer $\left(\mathrm{ca} .20^{\circ} \mathrm{C}\right)$ and in winter $\left(\mathrm{ca} .13^{\circ} \mathrm{C}\right)$ (Fig. 3). The highest temperatures are recorded between $7.7 \mathrm{ka}$ and $5.8 \mathrm{ka}$ with temperatures up to 23 ${ }^{\circ} \mathrm{C}$ during summer and up to $16^{\circ} \mathrm{C}$ during winter (Fig. 3). During the last $5 \mathrm{kyr}$, summer SST weakly decreases, with slightly oscillating values between $22^{\circ} \mathrm{C}$ and $23^{\circ} \mathrm{C}$ (Fig. 3). In the same interval, winter SSTs are almost stable with average values of about $15^{\circ} \mathrm{C}$ (Fig. 3), although during the last 3 kyr, the winter temperatures are characterized by a slight increase.

These results suggest that, with the exception of the interval between 10.2 and $8.7 \mathrm{ka}$, our SST record shows values comparable with those derived from the alkenone-SST at the same site (Martrat et al., 2014), with the foram-based SST from other nearly records (Pérez-Folgado et al., 2003; Schirrmacher et al., 2019), and with the present-day SST in the region (Locarnini et al., 2013). On the basis of these considerations, only the last $8.6 \mathrm{kyr}$ record has been considered for the climate interpretation.

\section{Power spectral and wavelet analysis}

The power spectrum of total NAR shows prominent peaks (over the 95\% Confidence Level - C.L.) of periodicity ranging between $1100 \mathrm{yr}$ and $1700 \mathrm{yr}$ (IMF3) (Fig. 4a, c). The wavelet analysis reveals that periodicities are not evenly distributed through time and specifically the $1102 \mathrm{yr}$ cycle occurs from $12 \mathrm{ka}$ to about $4 \mathrm{ka}$ (Fig. 4c), while the $1693 \mathrm{yr}$ periodicity emerges since about 5 ka upwards (Fig. 4c). Significant peaks (over the $95 \%$ of C.L.) are observed at the periods of $\sim 4300 \mathrm{yr}$ and $~$ 
8000 yr all along the record (IMF 4, 5) (Fig. 4 d,e). Scattered distribution of cycles between $\sim 400$ and $\sim 700 \mathrm{yr}$ are also observed (IMF 2) (Fig. 4b).

\section{Discussion}

\section{Main hydrographic and climate variations}

Surface water modifications occurring in the last $11 \mathrm{ka}$ can be described by three main long-term (between 3-5000 c.a. years-long) steps: Phase I, II and III (Figs. 5-6).

\section{Phase I - the early Holocene humid period}

This phase straddles the early Holocene, between $11.5 \mathrm{ka}$ and $8 \mathrm{ka}$ and is subsequent to the Younger Dryas Stadial. The climate evolution of the latter stadial has been discussed in detail in Bazzicalupo et al. (2018) based on the same proxies and therefore not discussed in the present study. Phase I is marked by a gradual surface water temperature increase, well described by progressively growing abundances of both coccolithophore and foraminifera warm-water taxa, associated with increasing summer insolation (Fig. 5). During this phase, the distinct increase in both Syrocosphaera spp. and T. quinqueloba (Fig. 5) provides evidences of enhanced riverine/detrital input in surface waters. Syracosphaera spp. has been, in fact, related to enhanced supply of fresher and turbid upper layer (Ausín, et al., 2015b; Bazzicalupo et al., 2018; Colmenero-Hidalgo et al., 2004; Weaver and Pujol, 1988), while the cold taxon T. quinqueloba flourishes in high fertile and low density surface waters (Aksu et al., 2002; Hemleben et al., 1985; Pujol and Vergnaud-Grazzini, 1995; Triantaphyllou et al., 2010). Enhanced abundances of this taxon have been also related to areas influenced by continental runoff (Bartels-Jónsdóttir et al., 2015; Girone et al., 2013; Jonkers et al., 2010; Margaritelli et al., 2016; Rohling et al., 1997; Vallefuoco et al., 2012) and, in the Eastern Mediterranean, the increase in abundance of T. quinqueloba, during the deposition of sapropel layer $\mathrm{S} 1$, has been linked to a high tolerance for low salinity and highly stratified water conditions coupled with the presence of high nutrients and terrestrial organic material (Capotondi et al., 2004; Kontakiotis, 2016; Principato et al., 2006; Rohling et al., 1997; Zachariasse et al., 1997). The high abundance of small Gephyrocapsa during phase I (Fig. 6), also sustains nutrient availability in surface water (Gartner et al., 1987; Hernández-Almeida et al., 2011; Okada and Wells, 1997; Takahashi and Okada, 2000). A concomitant expansion of Quercus during phase I (Fig. 5) highlights enhanced humidity on land (Combourieu-Nebout et al., 2009) likely in relation with extreme seasonality during precession minima/insolation maxima (Fig. 5) and increased autumn/winter westerlies-carried rains over the western Mediterranean, which supports enhanced supply of fresher water into the basin. This scenario seems to reflect a regional climate condition since it is consistent with the establishment of the Early 
339 Holocene humid phase, occurring between 11.5 and 7 ka (Jalut et al., 2009; Magny et al., 2002, 2013; 340 Peyron et al., 2017; Zanchetta et al., 2007; Zielhofer et al., 2017) and with additional evidences of 341 autumn/winter precipitation increase over the northern Mediterranean borderlands during northern 342 Hemisphere insolation maxima (Kutzbach et al., 2013; Meijer and Tuenter, 2007; Toucanne et al., 343 2015; Tzedakis, 2007). Phase I is within the interval of sapropel layer S1 deposition in the Eastern 344 Mediterranean (10.8-6.1 ka, De Lange et al., 2008), developed during maximum summer insolation, 345 that contributed, through the enhanced monsoon precipitation, to increased runoff in the Eastern 346 Mediterranean (Howell and Thunell, 1992; Rohling et al., 2002, 2004, 2015; Rossignol-Strick, 1985; 347 Rossignol-Strick et al., 1982). Our data evidence that freshwater runoff during sapropel events was 348 not restricted to the Eastern Mediterranean but was rather widespread over the entire Mediterranean 349 Sea due to increased rainfall (Bard et al., 2002; Kallel et al., 2000; Kallel and Labeyrie, 1997; 350 Toucanne et al., 2015; Zanchetta et al., 2007), thus strengthening the connection between North 351 African summer monsoon and the increased western Mediterranean autumn/winter precipitation 352 during sapropel deposition (Toucanne et al., 2015). On the other hand, phase I straddles the final 353 phase of the deposition of ORL 1 as indicated by the decreasing, albeit still high, values of $\mathrm{C}_{37}$ (Fig. 354 5), and reduced deep water ventilation in the western Mediterranean (Frigola et al., 2007). Given the 355 time offset between the beginning of the ORL1 formation (14.5 ka, Martrat et al., 2014), and the 356 recorded enhanced riverine input and humidity on land at c.a. $11.5 \mathrm{ka}$, it appears unlikely that excess 357 precipitation was the driving force of the ORL1 formation in the western Mediterranean (Rogerson 358 et al., 2008). As stated in Bazzicalupo et al. (2018), shoaling of the nutricline and increased export 359 production at the sea floor are relevant mechanism in the ORL1 deposition at the study core.

\section{The 8.2 ka event}

The transition between phase I and the following phase II is characterized by higher absolute abundances of $N$. incompta between $\sim 8.6 \mathrm{ka}$ and $\sim 8.1 \mathrm{ka}$ (Fig. 6 ) and by a sharp warm water taxa decrease (Fig. 5), suggesting water cooling. In more detail, a sharp and brief cooling event of about $3{ }^{\circ} \mathrm{C}$ is recorded in annual, winter and summer SST (Fig. 6). An interruption of the surface water warming trend is also indicated by a decrease of warm water coccolith taxa in the early stage (Fig. 5). A concomitant temperate forest regression (Fig. 6) marks a short-term precipitation decrease episode.

This cooling episode is here related to the well-known cold and dry 8.2 ka event that punctuates the early Holocene evolution and it is broadly recognized in Greenland ice core records (Alley and Ágústsdóttir, 2005; Bond et al., 1997, 2001; Dansgaard et al., 1993; Lowe et al., 2008; Rasmussen et al., 2006; Rohling and Pälike, 2005) and in the Mediterranean (e.g. De Rijk et al., 1999; Lirer et al., 
2013; Rohling et al., 2002; Sprovieri et al., 2003). In the ODP Site 976, the modification of the water column structure indicated by calcareous plankton can be related to a southward displacement of the ITCZ (Intertropical Convergence Zone) and an intensified impact of harsher, higher-latitude climate conditions in the Mediterranean region (Rohling et al., 2002, 2004). Today, N. incompta does not dwell in the Alboran Sea due to the occurrence of deep pycnocline and nutricline (located at a depth of about $150-200 \mathrm{~m}$ ) and winter temperatures reaching $15^{\circ} \mathrm{C}$ (Pujol and Vergnaud Grazzini, 1995; Rohling et al., 1995). On the other hand, this taxon is abundant in the Gulf of Lion where strong winter mixing facilitates the advection of nutrients into the euphotic zone and, mainly, winter temperatures reach $12^{\circ} \mathrm{C}$ (Pujol and Vergnaud-Grazzini, 1995; Rohling et al., 1995).

The marked increase of coccolithophore production within the upper part of the $8.2 \mathrm{ka}$ event, as indicated by the peak in total NAR (Fig. 2), is likely the result of an important hydrographic modification occurring at this time, related to the enhanced Atlantic water inflow. This feature marks the onset of the following phase II as discussed below and is very well comparable with a similar peak in the coccolithophore absolute abundance at 8.2 ka recorded in the Alboran Sea by ColmeneroHidalgo et al. (2004) and related to the onset of gyre circulation into the basin.

\section{Phase II: the middle Holocene establishment of the modern oceanographic circulation}

Phase II represents the second major step in the hydrographic evolution of the basin. It develops between $8.2 \mathrm{ka}$ and about $5.3 \mathrm{ka}$, thus it nearly represents the middle Holocene portion of the record (Bárcena et al., 2004; Giraudeau, 1993). It is marked by a distinct abundance increase of F. profunda and a subsequent increase of $G$. inflata (Fig. 6) which replaces N. incompta. Florisphaera profunda is a deep photic zone dweller and thrives with a deep nutricline and water column stratification (Baumann et al., 2005; Incarbona et al., 2013; Sprovieri et al., 2012), while G. inflata is a deep living taxon and benefits from water column stability, a deep pycnocline and reduced upwelling conditions. The shift between G. inflata and N. incompta is in agreement with Rohling et al. (1995) that linked this event to the establishment of the modern front-dominated conditions in the Alboran Sea, when the amount of Atlantic water inflow was close to the present volume. At Site 976, the enhanced Atlantic inflow, following the deglaciation and the sea level rise, would have deepened the nutricline favoring $F$. profunda. In addition, it would have promoted both the development of the modern geostrophic front, where G. inflata proliferates (Pujol and Vergnaud-Grazzini,1995; Rohling et al., 1995) and the establishment of WAG (Ausín et al., 2015b; Pérez-Folgado et al., 2003; Rohling et al., 1995). This hydrographic evolution follows the culmination of the highest rate of global sea-level rise (Lambeck et al., 2014). Concurrently to the development of a deep nutricline, high annual and seasonal SSTs are recorded (Fig. 6) also marked by the increase of the tropical taxon T. sacculifer 
(Fig. 6). Conversely, small Gephyrocapsa and neogloboquadrinids decrease (Fig. 6). We suggest that anomalous sea-surface warmer conditions during this period promoted a prolonged water column stratification, deepening of the thermocline (nutricline) and decrease of winter wind-induced mixing. These conditions contributed to a higher increase of warm and oligotrophic taxa, that currently thrives during mid-summer in the Mediterranean Sea (Bárcena et al., 2004; Pujol and Vergnaud-Grazzini, 1995), and decreasing of those taxa more related to nutrient-rich conditions such as small Gephyrocapsa and neogloboquadrinids. The occurrence of G. bulloides during this phase (Fig. 6) is consistent with its opportunistic behavior (Pujol and Vergnaud-Grazzini, 1995; Rohling et al., 1997; Schiebel et al., 2001) and its favorite habitat, highly dependent on enhanced food availability, related to strong seasonal contrast or river input. High abundances of temperate forest in the early stage of phase II (Fig. 6) suggest still wet climate conditions on land. This phase, although coeval with the younger portion of S1, is subsequent to the end of ORL 1 deposition in the Alboran Sea (Fig. 5). Deep anoxia in the western basin is in fact independent of that of the eastern basin (Rogerson et al., 2008) and ORL 1 termination is related to the $8.2 \mathrm{ka}$ event and to the establishment of the modern frontdominated conditions in the western Mediterranean (Cacho et al., 2002; Rogerson et al., 2008). During phase II, differently from phase I occurring during ORL1 deposition and characterized by shoaling of the nutricline and enhanced productivity in surface water (Bazzicalupo et al., 2018), the calcareous plankton assemblages indicate stratified conditions in column water and deep nutricline, which likely prevented productivity in surface water and export production at the sea floor. This datum supports the hypothesis that productivity, although does not represent the triggering mechanism, may provide a secondary control in the ORL formation (Rogerson et al., 2008).

\section{Phase III: the late Holocene reduced seasonality}

This phase is marked by the coeval increase of small Gephyrocapsa and G. bulloides, at c.a. 5.3 ka (Fig. 6), suggesting increased nutrient availability in surface waters. These taxa are, in fact, considered high surface water productivity proxies (Barcena et al., 2004; Colmenero-Hidalgo et al., 2004; Gartner et al., 1987; Pujol and Vergnaud-Grazzini, 1995 Takahashi and Okada, 2000). The enhanced abundances of the deep mixed dweller T. truncatulinoides (Fig. 6) support more intense seasonal and prolonged mixing. Elevated abundances of T. truncatulinodes from sediment trap in the Gulf of Lions have been related to increased winter mixing conditions (Rigual-Hernández et al., 2012). On the other hand, the high abundance of F. profunda and G. inflata (Fig. 6) is still in relation with the modern front-dominated conditions in the Alboran Sea and deep nutricline, originating at the onset of phase II. Oscillations in the absolute abundances of $F$. profunda as well as of small Gephyrocapsa (Fig. 6) are likely in relation with short-term fluctuations in total NAR, which are 
441 discussed in more detail below. Foraminifera warm-water taxa, together with G. ruber group and to 442 a less degree warm water coccolith taxa, show a general decreasing trend (Fig. 5). The summer SST 443 record (Fig. 6) is in line with reducing summer insolation trend (Fig. 5) and with evidence from the 444 western Mediterranean terrestrial record of reduced seasonality (cooler summers and warmer winters) 445 during the transition to late Holocene (Ramos-Román et al., 2018). The aridification process, 446 accompanying the reduced seasonality at this time is highlighted, in the pollen record, by an increase 447 in Artemisia at around $4 \mathrm{ka}$ at the studied core (Fig. 6), and by several coeval Mediterranean records 448 (Desprat et al., 2013; Fletcher et al., 2012; Fletcher and Sánchez Goñi, 2008; Jalali et al., 2016; Jalut 449 et al., 2000, 2009; Magny et al., 2013; Ramos-Román et al., 2018).

450 The last $3.5 \mathrm{kyr}$ of phase III are marked by a relevant increase of T. sacculifer (Fig. 6). The distribution 451 pattern of this taxon is punctuated by three main short-term pulses (Ts1-Ts3 in Fig. 6), not previously 452 recorded in the western Mediterranean. Trilobatus sacculifer mainly occurs in warm and oligotrophic 453 tropical and sub-tropical waters with low seasonality (Bé and Hutson, 1977; Fraile et al., 2008; 454 Hemleben et al., 1989; Vincent and Berger, 1981). Today this taxon reaches its maximum abundance 455 in the Eastern Mediterranean basin and in the Red Sea, where low nutrient and warm surface waters 456 prevail throughout the year, due to the relatively stable deep pycnocline (Kallel and Labeyrie, 1997; 457 Kucera et al., 2005; Pujol and Vergnaud-Grazzini, 1995; Siccha et al., 2009). In the Red Sea, its 458 increasing trend, during the Holocene, has been also related to more arid conditions during reduced 459 monsoon climate system and prevailing eastern Mediterranean climate system (Edelman-Furstenberg 460 et al., 2009). In our record, the last $3.5 \mathrm{kyr}$ are characterized by a reduction of seasonal thermal

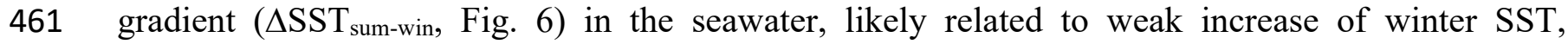
462 concomitant with ameliorate climate condition on land, as suggested by coeval relative increases of 463 temperate forests in the pollen assemblages (Fig. 6). A positive correlation between T. sacculifer and 464 weaker winter conditions and stratification has been also found in the Arabian Sea (Munz et al., 465 2015). We suggest that, at Site 976, relatively higher winter SSTs (with values exceeding $15^{\circ} \mathrm{C}$ ) with 466 respect to the earlier interval, developed more stable year-round surface water conditions in the basin 467 favoring the increase of $T$. sacculifer in the last $3.5 \mathrm{kyr}$. Such conditions could probably represent the 468 response to changes in hydrological conditions in the adjacent Iberian basin, related to the reduction 469 of meltwater discharge in the North Atlantic (Bond et al., 2001). In the Gulf of Cádiz, according to 470 Schirrmacher et al. (2019), larger seasonal SST contrasts, during the Holocene, are related to periods 471 of enhanced iceberg discharge; the northward heat transport was blocked due to freshwater forcing 472 in the North Atlantic resulting in colder winter temperatures and higher summer temperatures due to 473 a seasonal northward migration of Intertropical Convergence Zone (ITCZ). This mechanism is similar 474 to the one proposed by Repschläger et al. (2017) for the early Holocene, when reinforcements of 
northward heat transport and migration of Subtropical Gyre is found during periods of weak north Atlantic meltwater discharge. Similarly, we retain that the decrease in the drift ice index during the last 3 kyr (Bond et al., 2001), could have promoted higher northward advection of warmer water masses that could have also reached the Alboran Sea through the Strait of Gibraltar, favoring the instauration of a lower seasonal thermal gradient. The three distinct peaks of $T$. sacculifer, centered at about $2.9 \mathrm{ka}, 1.8 \mathrm{ka}$ and $0.7 \mathrm{ka}$, trace the occurrence of short warm pulses at the core location. They appear chronologically correlated with the short-term warm and dry events identified in northwestern Africa lakes and in the Adriatic Sea (Piva et al., 2008; Zielhofer et al., 2017). The phase Ts1 is also chronologically correlated with the warm phase recognized by Margaritelli et al. (2016) during the Middle Bronze Age-Iron Age in the central Mediterranean.

\section{Millennial scale variations}

Since the WAG establishment in the Alboran Sea at ca. $8 \mathrm{ka}$, total NAR values show a series of millennial-scale fluctuations over the middle and late Holocene at Site 976 (Fig. 7). This pattern indicates that high-frequency variations in the coccolithophore productivity are superimposed to the main climate phases. Connecting coccolithophore productivity to environmental proxies is a complex task since multiple relationships might affect the link between the various signals. A certain chronological uncertainty is also added, when comparing different sites with different age models. In order to unravel the forcing mechanism responsible for coccolithophore productivity variations at the studied core, we compared a few coccolithophore proxies with the pattern of $\delta^{18} \mathrm{O}_{\text {seawater }}$ available at the ODP Site 976 (Jiménez-Amat and Zahn, 2015), as a proxy of local surface water salinity variation. We have also performed a comparison with the detrended $\delta^{18} \mathrm{O}_{\text {speleothem }}$ curve (Smith et al., 2016), which represents a high-resolution archive of quasi-cyclical events of relatively wet-to-dry climatic conditions over Iberia, with a $\sim 1500$ year frequency (Smith et al., 2016). This trend is significantly correlated with the NAO index (Olsen et al., 2012) (Fig. 7). A relationship between coccolithophore productivity and NAO modes has been recently suggested in the Alboran Sea by Ausín et al. (2015a). These authors indicate weakened (intensified) upwelling, related to weaker (stronger) westerlies, responsible for reduced (reinforced) WMDW in the Gulf of Lions. In this scenario, the NAO circulation mode is the forcing mechanism of coccolithophore variability. Intensified upwelling would have been promoted by stronger westerlies blowing over the Gulf of Lions, during a NAO mode. These conditions would have promoted major WMDW formation and simultaneous enhancement of the AJ influx, both fluctuating in-phase (Ausín et al., 2015a; García Lafuente et al., 2002, 2007). The AJ would have migrated southward, allowing the cool subsurface waters to fill the area left behind the jet (Sarhan, 2000) and thus promoting upwelling. In the present work, a first 
comparison between datasets indicates that low salinity phases (lighter $\delta^{18} \mathrm{O}_{\text {seawater }}$ ) are concurrent with high values of $G$. oceanica (Fig. 7). The occurrence of $G$. oceanica within the western Mediterranean basin has been often related to Atlantic surface water inflows (Álvarez et al., 2010; Bárcena et al., 2004; Bazzicalupo et al., 2018; Knappertsbusch, 1993; Oviedo et al., 2017). The positive correlation of the coccolithophore taxon with salinity minima at Site 976, further supports the relation between $G$. oceanica and Atlantic surface water inflows, since salinity minimum in the Alboran Sea essentially traces phases of enhanced Atlantic water into the basin (Font et al., 1998; Sarhan et al., 2000; Viúdez et al., 1996). Consequently, we use the lighter values of $\delta^{18} \mathrm{O}_{\text {seawater }}$ and the increased abundance of G. oceanica as proxies of Atlantic inflow in the Alboran Sea (Fig. 7), which both provide a regime of cyclical Atlantic water inflow intensity in the basin. Coccolithophore productivity variations, expressed as total NAR, display distinct pulses, well-correlated with the pattern of the changing Atlantic inflow intensity and with the concomitant occurrence of alternating dry/wet phases in the Iberia $\delta^{18} \mathrm{O}_{\text {speleothem }}$ (Fig. 7). Therefore, the various proxies point out to a coupling between enhanced coccolithophore productivity (high total NAR values), intensified

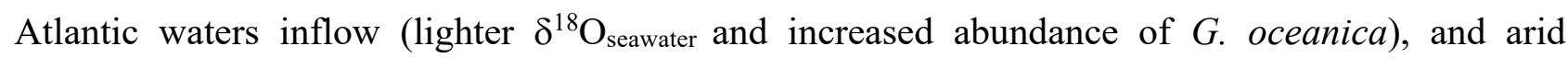
conditions over the Iberia Peninsula (peaks in $\delta^{18} \mathrm{O}_{\text {speleothem}}$ ), correlated with $\mathrm{NAO}+$ phases (Fig. 7). Our data support the model proposed by Ausín et al. (2015a), and specifically the relation between coccolithophore productivity, Atlantic inflow and WMDW strength, although the dataset at site 976 indicate an opposite relationship between coccolithophore productivity and NAO mode. According to the present results, enhanced Atlantic water inflow occurred during a persistent NAO+ index (Fig. 7); the latter would have strengthened the north-westerlies over the northwestern Mediterranean basin, promoting a reinforcement of deepwater overturning and in turn increased the AJ (Fig. 8). The suggested relation between NAO mode and WMDW strength is in agreement with results from today's survey in the western Mediterranean (Rixen et al., 2005) and with the proposed relationship between strengthening of the WMDW and NAO variability in the past. In fact, during the Holocene and the Dansgaard-Oeschger events NAO + phases would have strengthen the northwesterlies over the northwestern Mediterranean, enhancing the WMDW formation (Frigola et al., 2007; Moreno et al., 2002, 2004, 2005; Nieto-Moreno et al., 2011). The scenario is also consistent with the observed decadal-variability between NAO intensity and upwelling strength highlighted in the western Mediterranean (Vargas-Yáñez et al., 2008). A possible reasonable explanation for the differing interpretations between the present work and the Ausín et al. (2015a) study, is that the latter authors based their paleoceanographic reconstruction on oscillations of the $F$. profunda NAR abundances in the Alboran Sea. In Ausín et al. (2015a), F. profunda NAR peaks have been linked to the intensification of the upwelling conditions in the area. Recent data establish a precise relationship 
543 between $F$. profunda and primary productivity levels in today's low-latitude oceans (Hernández544 Almeida et al., 2019) and suggest that the link between $F$. profunda abundance and net primary 545 productivity in the Mediterranean Sea is not straight forward thus discouraging the use of this taxon 546 as a productivity indicator into the basin (Hernández-Almeida et al., 2019).

\section{External and internal forcing mechanisms of coccolithophore productivity cycles}

549 The time series analysis performed on the total NAR record confirms the occurrence of millennial550 scale periodicities in coccolithophore productivity during the Holocene and highlights two main 551 periodicities through the record: the first one of $\sim 1100 \mathrm{yr}$ (from 12.5 to c.a. $5 \mathrm{ka}$ ) and the second one 552 of $\sim 1700 \mathrm{yr}$ (from 5 to $0.19 \mathrm{ka}$ ) (Fig. 4c). The results of spectral and wavelength analyses indicate 553 that coccolithophore productivity changes in the Alboran Sea were modulated both by external (solar) 554 and internal (oceanic-atmospheric) forcing. In fact, the $\sim 1100 \mathrm{yr}$-cycles appear close to the $\sim 1000$ 555 yr cycle identified during the early Holocene in solar proxies in North Atlantic records and in IRD 556 record (Debret et al., 2007, 2009). They are also detected in the western Mediterranean pollen record, 557 which displays a periodic component of $\sim 900 \mathrm{yr}$ (Fletcher et al., 2012) and of $\sim 1100 \mathrm{yr}$ (Ramos558 Román et al., 2018) during the early and middle Holocene. On the other hand, cycles of $\sim 1700 \mathrm{yr}$ 559 are very close to the 1600-year cycle dominating during the last $5000 \mathrm{yr}$ in several paleoclimate 560 records (Debret et al., 2007; 2009 and references therein) and related to internal 561 (oceanic/atmospheric) forcing. A similar shift in periodicity to a dominant $\sim 1750$ oscillation in the 562 last $6 \mathrm{ka}$ (Fletcher et al., 2012) and 1600 yr-cycle (Ramos-Román et al., 2018) in the last $4.7 \mathrm{ka}$ has

563 been detected in the western Mediterranean in the pollen record and is related to the influence of 564 NAO-like circulation in the mid-late Holocene. The similar pattern in cyclicity observed in the 565 present study in NAR pattern in the Alboran Sea strengthens the relation between coccolithophore productivity/hydrographic changes and atmospheric variability modulated by NAO fluctuations and sustains the occurrence of a periodicity change through the Holocene from a dominant external (solar) to a dominant internal (oceanic/atmospheric) forcing.

\section{Conclusions}

571 The calcareous plankton assemblage (coccolithophore and foraminifera) of the ODP Site 976 from the Alboran Sea has been studied at a centennial-scale resolution, to investigate the climate variability and the forcing mechanisms affecting the western Mediterranean basin during the last $12.5 \mathrm{ka}$.

574 Coccolithophore and planktonic foraminifera dataset is integrated with pollen and geochemical data 575 available at the site. During a first step, between 11.5 and $8.2 \mathrm{ka}$, calcareous plankton assemblage 576 clearly traces increasing temperature and freshwater arrival, related to riverine input in the basin, 
during a period of insolation maxima. The timing of this phase in the Alboran Sea is quasi concomitant with sapropel S1 deposition in the eastern Mediterranean, suggesting a connection between the monsoonal mechanism for sapropel formation and high rainfall conditions in Northwestern Europe. Following an abrupt surface water temperature decrease correlated with humidity reduction and centered at $8.2 \mathrm{ka}$, the second phase $(8-4.6 \mathrm{ka})$ is marked by a profound change in the planktonic assemblages, reflecting a more stratified water column, the deepening of the nutricline following a sea level rise and the instauration of the modern gyre circulation. The third final phase (4.6-0.19 ka) is characterized by reduced seasonality (cooler summers and warmer winters), enhanced surface water mixing and increased aridification on land related with a decrease in summer insolation. Short-term cyclicity occurs in coccolithophore productivity, with a clear pattern mainly occurring since the establishment of the modern circulation. Millennial-cycles of increased coccolithophore productivity are associated with enhanced inflows of Atlantic water from the Gibraltar strait modulated by $\mathrm{NAO}+$ mode. The proposed scenario strengthens the role of hydrographic changes and atmospheric variability modulated by NAO fluctuations on coccolithophore productivity in the Alboran Sea. The results of the spectral analysis add information on the value of coccolithophores in recording environmental changes and highlight that coccolithophore productivity is modulated by both external (solar) and internal (oceanicatmospheric) forcing. A shift in periodicity from a dominant $\sim 1100 \mathrm{yr}$ oscillations to $\sim 1600 \mathrm{yr}$ periodicity occurs at about $4 \mathrm{ka}$ and appears in agreement with enhanced influence of NAO-like circulation during the late Holocene.

\section{Acknowledgements}

Two anonymous reviewers are greatly acknowledged for their valuable contributions which improved the early version of this manuscript. The authors thank the Ocean Drilling Program for providing the samples of ODP Site 976. This research was financially supported by the Geoscience $\mathrm{PhD}$ scholarship, Università degli Studi di Bari, and benefited of instrumental upgrades from "Potenziamento Strutturale PONa3_00369 dell'Università degli Studi di Bari, Laboratorio per lo Sviluppo Integrato delle Scienze e delle Tecnologie dei Materiali Avanzati e per dispositivi innovativi (SISTEMA). E.S. was funded by a postdoctoral fellowship (SFRH/ BPD/111433/2015) from Fundação para a Ciência e a Tecnologia (FCT).

\section{References}

Aksu AE, Hiscott RN, Kaminski MA, et al. (2002) Last glacial-Holocene paleoceanography of the 

Black Sea and Marmara Sea: stable isotopic, foraminiferal and coccolith evidence. Marine Geology 190(1-2). Elsevier: 119-149. DOI: 10.1016/S0025-3227(02)00345-6.

Alley RB and Ágústsdóttir AM (2005) The 8k event: Cause and consequences of a major Holocene abrupt climate change. Quaternary Science Reviews 24(10-11): 1123-1149. DOI: 10.1016/j.quascirev.2004.12.004.

Álvarez MC, Amore OF, Cros LL, et al. (2010) Coccolithophore biogeography in the Mediterranean Iberian margin. Revista Española de Micropaleontologia 42(3): 359-371.

André A, Weiner A, Quillévéré F, et al. (2012) The cryptic and the apparent reversed: lack of genetic differentiation within the morphologically diverse plexus of the planktonic foraminifer Globigerinoides sacculifer. Paleobiology 39(01). GeoScienceWorld: 21-39. DOI: 10.1666/0094-8373-39.1.21.

Aurahs R, Treis Y, Darling K, et al. (2011) A revised taxonomic and phylogenetic concept for the planktonic foraminifer species Globigerinoides ruber based on molecular and morphometric evidence. Marine Micropaleontology 79(1-2). Elsevier: 1-14.

Ausín B, Flores JA, Sierro FJ, Cacho I, et al. (2015a) Atmospheric patterns driving Holocene productivity in the Alboran Sea (Western Mediterranean): A multiproxy approach. The Holocene 25(4): 583-595. DOI: 10.1177/0959683614565952.

Ausín B, Flores JA, Sierro FJ, Bárcena MA, et al. (2015b) Coccolithophore productivity and surface water dynamics in the Alboran Sea during the last 25kyr. Palaeogeography, Palaeoclimatology, Palaeoecology 418. Elsevier B.V.: 126-140. DOI: 10.1016/j.palaeo.2014.11.011.

Bárcena MA, Cacho I, Abrantes F, et al. (2001) Paleoproductivity variations related to climatic conditions in the Alboran Sea (western Mediterranean) during the last glacial-interglacial transition: The diatom record. Palaeogeography, Palaeoclimatology, Palaeoecology 167(3-4): 337-357. DOI: 10.1016/S0031-0182(00)00246-7.

Bárcena MA, Flores JA, Sierro FJ, et al. (2004) Planktonic response to main oceanographic changes in the Alboran Sea (Western Mediterranean) as documented in sediment traps and surface sediments. Marine Micropaleontology 53(3-4): 423-445. DOI: 10.1016/j.marmicro.2004.09.009. 
Bard E, Delaygue G, Rostek F, et al. (2002) Hydrological conditions over the western Mediterranean basin during the deposition of the cold Sapropel 6 (ca. $175 \mathrm{kyr}$ BP). Earth and Planetary Science Letters 202(2). Elsevier: 481-494. DOI: 10.1016/S0012-821X(02)00788-4.

Bartels-Jónsdóttir HB, Voelker AHL, Abrantes FG, et al. (2015) High-frequency surface water changes in the Tagus prodelta off Lisbon, eastern North Atlantic, during the last two millennia. Marine Micropaleontology 117. Elsevier: 13-24. DOI: 10.1016/J.MARMICRO.2015.03.001.

Baumann K-H, Boeckel B, Frenz M, et al. (2004) Coccolith contribution to South Atlantic carbonate sedimentation; Coccolithophores; from molecular processes to global impact. In: Coccolithophores - From Molecular Processes to Global Impact, pp. 367-402. DOI: 10.1016/S0079-6352(99)80122-2.

Baumann K-H, Andruleit H, Böckel B, et al. (2005) The significance of extant coccolithophores as indicators of ocean water masses, surface water temperature, and palaeoproductivity: a review. Paläontologische Zeitschrift 79(1): 93-112. DOI: 10.1007/BF03021756.

Bazzicalupo P, Maiorano P, Girone A, et al. (2018) High-frequency climate fluctuations over the last deglaciation in the Alboran Sea, Western Mediterranean: Evidence from calcareous plankton assemblages. Palaeogeography, Palaeoclimatology, Palaeoecology 506. Elsevier: 226-241. DOI: 10.1016/J.PALAEO.2018.06.042.

Bé AWH and Hutson WH (1977) Ecology of Planktonic Foraminifera and Biogeographic Patterns of Life and Fossil Assemblages in the Indian Ocean. Micropaleontology 23(4). The Micropaleontology Project., Inc.: 369. DOI: 10.2307/1485406.

Boeckel B and Baumann K-H (2004) Distribution of coccoliths in surface sediments of the southeastern South Atlantic Ocean: Ecology, preservation and carbonate contribution. Marine Micropaleontology 51(3-4): 301-320. DOI: 10.1016/j.marmicro.2004.01.001.

Bond G, Showers W, Cheseby M, et al. (1997) A pervasive Millennial-scale cycle in the North Atlantic Holocene Climate. Science 278: 1257-1266.

Bond G, Kromer B, Beer J, et al. (2001) Persistent solar influence on North Atlantic climate. Science 294(5549): 2130-2136. DOI: 10.1126/science.1065668.

Cacho I, Grimalt JO, Pelejero C, et al. (1999) Dansgaard-Oeschger and Heinrich event imprints in Alboran Sea paleotemperatures. Paleoceanography 14(6). John Wiley \& Sons, Ltd: 698-705. 
Cacho I, Grimalt JO, Canals M, et al. (2001) Variability of the western Mediterranean Sea surface temperature during the last 25,000 years and its connection with the Northern Hemisphere climatic change. Paleoceanography 16(1): 40-52. DOI: 10.1029/SP010.

Cacho I, Grimalt JO and Canals M (2002) Response of the Western Mediterranean Sea to rapid climatic variability during the last 50,000 years: A molecular biomarker approach. Journal of Marine Systems 33-34: 253-272. DOI: 10.1016/S0924-7963(02)00061-1.

Capotondi L, Maria Borsetti A and Morigi C (1999) Foraminiferal ecozones, a high resolution proxy for the late Quaternary biochronology in the central Mediterranean Sea. Marine Geology 153(1-4). Elsevier: 253-274. DOI: 10.1016/S0025-3227(98)00079-6.

Capotondi L, Soroldoni E, Principato MS, et al. (2004) Late Quaternary planktonic foraminiferal distributions : problems related to size fraction. Proceedings of the First Italian Meeting on Environmental Micropaleontology (9): 1-6.

Català A, Cacho I, Frigola J, et al. (2018) Holocene hydrography evolution in the Alboran Sea: a multi-record and multiproxy comparison. Climate of the Past Discussions 15(3): 927-942.

Cita MB, Vergnaud-Grazzini C, Robert C, et al. (1977) Paleoclimatic Record of a Long Deep Sea Core from the Eastern Mediterranean. Quaternary Research 8(2). Cambridge University Press: 205-235. DOI: 10.1016/0033-5894(77)90046-1.

Colmenero-Hidalgo E, Flores JA and Sierro FJ (2002) Biometry of Emiliania huxleyi and its biostratigraphic significance in the Eastern North Atlantic Ocean and Western Mediterranean Sea in the last 20000 years. Marine Micropaleontology 46(3-4): 247-263. DOI: 10.1016/S0377-8398(02)00065-8.

Colmenero-Hidalgo E, Flores JA, Sierro FJ, et al. (2004) Ocean surface water response to shortterm climate changes revealed by coccolithophores from the Gulf of Cadiz (NE Atlantic) and Alboran Sea (W Mediterranean). Palaeogeography, Palaeoclimatology, Palaeoecology 205(34): 317-336. DOI: 10.1016/j.palaeo.2003.12.014.

Comas M, Zahn R and Klaus A (1996) Ocean Drilling Program LEG 161 Preliminary Report Mediterranean Sea II - The Western Mediterranean. ODP Preliminary Report. 
698

699

700

701

702

703

704

705

706

707

708

709

710

711

712

713

714

715

716

717

718

719

720

721

722

723

724

pressure stability over the western Mediterranean during the North Atlantic cold events of the past 50 k.y. Geology 30(10): 863.

Combourieu-Nebout N, Peyron O, Dormoy I, et al. (2009) Rapid climatic variability in the west Mediterranean during the last 25000 years from high resolution pollen data. Climate of the Past 5: 503-521. DOI: 10.1109/IGARSS.2010.5652499.

Corselli C, Principato MS, Maffioli P, et al. (2002) Changes in planktonic assemblages during sapropel S5 deposition: Evidence from Urania Basin area, eastern Mediterranean. Paleoceanography 17(3). DOI: 10.1029/2000PA000536.

D'Ortenzio F and D'Alcalà MR (2009) On the trophic regimes of the Mediterranean Sea: A satellite analysis. Biogeosciences 6(2): 139-148. DOI: 10.5194/bg-6-139-2009.

Dansgaard W, Johnsen SJ, Clausen HB, et al. (1993) Evidence for general instability of the past climate from a 250-kyr ice-core record. Nature 364: 218-220. DOI: 10.2307/1178566.

Darling KF, Kucera M, Kroon D, et al. (2006) A resolution for the coiling direction paradox in Neogloboquadrina pachyderma. Paleoceanography 21(2). John Wiley \& Sons, Ltd: n/a-n/a. DOI: 10.1029/2005PA001189.

De Lange GJ, Thomson J, Reitz A, et al. (2008) Synchronous basin-wide formation and redoxcontrolled preservation of a Mediterranean sapropel. Nature Geoscience 1(9): 606-610. DOI: $10.1038 /$ ngeo 283 .

De Rijk S, Troelstra SR and Rohling EJ (1999) Benthic foraminiferal distribution in the Mediterranean Sea. The Journal of Foraminiferal Research 29(2). GeoScienceWorld: 93-103. DOI: $10.2113 /$ gsjfr.29.2.93.

Debret M, Bout-Roumazeilles V, Grousset F, et al. (2007) The origin of the 1500-year climate cycles in Holocene North-Atlantic records. Available at: https://hal-sde.archivesouvertes.fr/hal-00330731/ (accessed 20 June 2019).

Debret M, Sebag D, Crosta X, et al. (2009) Evidence from wavelet analysis for a mid-Holocene transition in global climate forcing. Quaternary Science Reviews 28(25-26). Elsevier Ltd: 2675-2688. DOI: 10.1016/j.quascirev.2009.06.005.

Desprat S, Combourieu-Nebout N, Essallami L, et al. (2013) Deglacial and holocene vegetation and climatic changes in the southern central Mediterranean from a direct land-sea correlation. 
Edelman-Furstenberg Y, Almogi-Labin A and Hemleben C (2009) Palaeoceanographic evolution of the central Red Sea during the late Holocene. Holocene 19(1): 117-127. DOI: $10.1177 / 0959683608098955$.

Fletcher WJ and Sánchez Goñi MF (2008) Orbital- and sub-orbital-scale climate impacts on vegetation of the western Mediterranean basin over the last 48,000 yr. Quaternary Research 70(3): 451-464. DOI: 10.1016/j.yqres.2008.07.002.

Fletcher WJ, Debret M and Sanchez Goñi M (2012) The Holocene frequency millennial oscillation in western Mediterranean climate: Implications for past dynamics of the North Atlantic atmospheric westerlies. The Holocene 23(2): 153-166. DOI: 10.1177/0959683612460783.

Flores JA and Sierro FJ (1997) Revised technique for calculation of calcareous nannofossil accumulation rates. Micropaleontology 43(3): 321-324. DOI: 10.2307/1485832.

Flores JA, Gersonde RR, Sierro FJ, et al. (2000) Southern ocean pleistocene calcareous nannofossil events: Calibration with isotope and geomagnetic stratigraphies. Marine Micropaleontology 40(4): 377-402. DOI: 10.1016/S0377-8398(00)00047-5.

Font J, Millot C, Salas J, et al. (1998) The drift of Modified Atlantic Water from the Alboran Sea to the eastern Mediterranean. Scientia Marina 62(3): 211-216. DOI: 10.3989/scimar.1998.62n3211.

Font J, Puig P, Salat J, et al. (2007) Sequence of hydrographic changes in NW Mediterranean deep water due to the exceptional winter of 2005. Scientia Marina 71(2): 339-346. DOI: 10.3989/scimar.2007.71n2339.

Foster G (1996) Wavelets for period analysis of unevenly sampled time series. Astron. J. 112: 1709-1729.

Fraile I, Schulz M, Mulitza S, et al. (2008) Predicting the global distribution of planktonic foraminifera using a dynamic ecosystem model. Biogeosciences 5: 891-911.

Frigola J, Moreno A, Cacho I, et al. (2007) Holocene climate variability in the western Mediterranean region from a deepwater sediment record. Paleoceanography 22(2): 1-16. DOI: 10.1029/2006PA001307. 
Frigola J, Moreno A, Cacho I, et al. (2008) Evidence of abrupt changes in Western Mediterranean Deep Water circulation during the last 50 kyr: A high-resolution marine record from the Balearic Sea. Quaternary International 181(1): 88-104. DOI: 10.1016/j.quaint.2007.06.016.

Garcia-Gorriz E and Carr M-E (1999) The climatological annual cycle of satellite-derived phytoplankton pigments in the Alboran sea. Geophysical Research Letters 26(19): 2985-2988.

García Lafuente J, Fanjul EÁ, Vargas JM, et al. (2002) Subinertial variability in the flow through the Strait of Gibraltar. Journal of Geophysical Research 107(C10). John Wiley \& Sons, Ltd: 3168. DOI: 10.1029/2001JC001104.

García Lafuente J, Sánchez Román A, Díaz del Río G, et al. (2007) Recent observations of seasonal variability of the Mediterranean outflow in the Strait of Gibraltar. Journal of Geophysical Research 112(C10). John Wiley \& Sons, Ltd: C10005. DOI: 10.1029/2006JC003992.

Gartner S, Chow J and Stanton RJ (1987) Late Neogene paleoceanography of the Eastern Caribbean, the Gulf of Mexico, and the Eastern Equatorial Pacific. Marine Micropaleontology 12: $255-304$.

Gimeno L, Nieto R, Trigo RM, et al. (2010) Where Does the Iberian Peninsula Moisture Come From? An Answer Based on a Lagrangian Approach. Journal of Hydrometeorology 11(2): 421-436. DOI: 10.1175/2009JHM1182.1.

Giraudeau J (1993) Planktonic foraminiferal assemblages in surface sediments from the southwest African continental margin. Marine Geology 110(1-2). Elsevier: 47-62. DOI: 10.1016/00253227(93)90104-4.

Giraudeau J, Pierre C and Herve L (2001) A Late Quaternary, High-resolution Record Of Planktonic Foraminiferal Species Distribution in The Southern Benguela Region: SITE 1087. Proceedings of the Ocean Drilling Program, Scientific Results.

Giraudeau J, Grelaud M, Solignac S, et al. (2010) Millennial-scale variability in Atlantic water advection to the Nordic Seas derived from Holocene coccolith concentration records. Quaternary Science Reviews 29(9-10). Elsevier Ltd: 1276-1287. DOI: 10.1016/j.quascirev.2010.02.014.

Girone A, Maiorano P, Marino M, et al. (2013) Calcareous plankton response to orbital and millennial-scale climate changes across the Middle Pleistocene in the western Mediterranean. 
Grelaud M, Beaufort L, Cuven S, et al. (2009) Glacial to interglacial primary production and El Niño-Southern Oscillation dynamics inferred from coccolithophores of the Santa Barbara Basin. Paleoceanography 24(1): 1-15. DOI: 10.1029/2007PA001578.

Hayes A, Kucera M, Kallel N, et al. (2005) Glacial Mediterranean sea surface temperatures based on planktonic foraminiferal assemblages. Quaternary Science Reviews 24(7-9). Pergamon: 999-1016. DOI: 10.1016/J.QUASCIREV.2004.02.018.

Heburn GW and La Violette PE (1990) Variations in the structure of the anticyclonic gyres found in the Alboran Sea. Journal of Geophysical Research 95(C2): 1599. DOI: 10.1029/JC095iC02p01599.

Hemleben C, Spindler M, Breitinger I, et al. (1985) Field and laboratory studies on the ontogeny and ecology of some globorotalid species from the Sargasso Sea off Bermuda. Journal of Foraminiferal Research. $v$.

Hemleben C, Spindler M and Anderson OR (1989) Taxonomy and Species Features. In: Modern Planktonic Foraminifera. New York, NY: Springer New York, pp. 8-32. DOI: 10.1007/978-14612-3544-6_2.

Hernández-Almeida I, Bárcena MA, Flores JA, et al. (2011) Microplankton response to environmental conditions in the Alboran Sea (Western Mediterranean): One year sediment trap record. Marine Micropaleontology 78(1-2). Elsevier: 14-24. DOI: 10.1016/J.MARMICRO.2010.09.005.

Hernández-Almeida I, Ausín B, Saavedra-Pellitero M, et al. (2019) Quantitative reconstruction of primary productivity in low latitudes during the last glacial maximum and the mid-to-late Holocene from a global Florisphaera profunda calibration dataset. Quaternary Science Reviews 205: 166-181. DOI: 10.1016/J.QUASCIREV.2018.12.016.

Howell MW and Thunell RC (1992) Organic carbon accumulation in Bannock Basin: Evaluating the role of productivity in the formation of eastern Mediterranean sapropels. Marine Geology 103(1-3). Elsevier: 461-471. DOI: 10.1016/0025-3227(92)90032-D. 

spectrum for nonlinear and nonstationary time series analysis. Proc. Roy. Soc. London A454: 903-995.

Hurrell JW (1995) Decadal Trends in the North Atlantic Oscillation: Regional Temperatures and Precipitation. Science 269: 676-679.

Incarbona A, Sprovieri M, Di Stefano A, et al. (2013) Productivity modes in the mediterranean sea during dansgaard-oeschger (20,000-70,000yr ago) oscillations. Palaeogeography, Palaeoclimatology, Palaeoecology 392. Elsevier B.V.: 128-137. DOI: 10.1016/j.palaeo.2013.09.023.

Jalali B, Sicre M-A, Bassetti MA, et al. (2016) Holocene climate variability in the North-Western Mediterranean Sea (Gulf of Lions). Climate of the Past 12(1): 91-101. DOI: 10.5194/cp-1291-2016.

Jalali B, Sicre M-A, Kallel N, et al. (2017) High-resolution Holocene climate and hydrological variability from two major Mediterranean deltas (Nile and Rhone). Holocene 27(8): 11581168. DOI: $10.1177 / 0959683616683258$.

Jalut G, Esteban Amat A, Bonnet L, et al. (2000) Holocene climatic changes in the Western Mediterranean, from south-east France to south-east Spain. Palaeogeography, Palaeoclimatology, Palaeoecology 160(3-4): 255-290. DOI: 10.1016/S0031-0182(00)000754.

Jalut G, Dedoubat JJ, Fontugne M, et al. (2009) Holocene circum-Mediterranean vegetation changes: Climate forcing and human impact. Quaternary International 200(1-2): 4-18. DOI: 10.1016/j.quaint.2008.03.012.

Jiménez-Amat P and Zahn R (2015) Offset timing of climate oscillations during the last two glacialinterglacial transitions connected with large-scale freshwater perturbation. Paleoceanography 30(6): 768-788. DOI: 10.1002/2014PA002710.

Jimenez-Espejo FJ, Martinez-Ruiz F, Sakamoto T, et al. (2007) Paleoenvironmental changes in the western Mediterranean since the last glacial maximum: High resolution multiproxy record from the Algero-Balearic basin. Palaeogeography, Palaeoclimatology, Palaeoecology 246(24): 292-306. DOI: 10.1016/j.palaeo.2006.10.005. 

fluctuations, and water mass circulation in the westernmost Mediterranean Sea since the Last Glacial Maximum. Geochemistry, Geophysics, Geosystems 9(11). DOI: 10.1029/2008GC002096.

Jonkers L, Brummer G-JA, C Peeters FJ, et al. (2010) Seasonal stratification, shell flux, and oxygen isotope dynamics of left-coiling. Paleoceanography 25. DOI: 10.1029/2009PA001849.

Jordan RW, Cros L and Young JR (2004) A revised classification scheme for living haptophytes. Micropaleontology 50(Suppl_1). GeoScienceWorld: 55-79. DOI: 10.2113/50.Suppl_1.55.

Kallel N and Labeyrie L (1997) Enhanced rainfall in the Mediterranean region during the last Sapropel Event. Oceanologica Acta.

Kallel N, Duplessy J-C, Labeyrie L, et al. (2000) Mediterranean pluvial periods and sapropel formation over the last 200000 years. Palaeogeography, Palaeoclimatology, Palaeoecology 157(1-2). Elsevier: 45-58. DOI: 10.1016/S0031-0182(99)00149-2.

Knappertsbusch M (1993) Geographic distribution of living and Holocene coccolithophores in the Mediterranean Sea. Marine Micropaleontology 21(1-3). Elsevier: 219-247. DOI: 10.1016/0377-8398(93)90016-Q.

Kontakiotis G (2016) Late Quaternary paleoenvironmental reconstruction and paleoclimatic implications of the Aegean Sea (eastern Mediterranean) based on paleoceanographic indexes and stable isotopes. Quaternary International 401. Elsevier Ltd: 28-42. DOI: 10.1016/j.quaint.2015.07.039.

Kucera M, Weinelt Mara, Kiefer T, et al. (2005) Reconstruction of sea-surface temperatures from assemblages of planktonic foraminifera: Multi-technique approach based on geographically constrained calibration data sets and its application to glacial Atlantic and Pacific Oceans. Quaternary Science Reviews 24(7-9 SPEC. ISS.). Pergamon: 951-998. DOI: 10.1016/j.quascirev.2004.07.014.

Kutzbach JE, He F, Vavrus SJ, et al. (2013) The dependence of equilibrium climate sensitivity on climate state: Applications to studies of climates colder than present. Geophysical Research Letters 40(14): 3721-3726. DOI: 10.1002/grl.50724.

Lambeck K, Rouby H, Purcell A, et al. (2014) Sea level and global ice volumes from the Last Glacial Maximum to the Holocene. Proceedings of the National Academy of Sciences 111(43): 
Laskar J, Robutel P, Joutel F, et al. (2004) A long-term numerical solution for the insolation

873

874

875

876

877

878

879

880

881

882

883

884

885

886

887

888

889

890

891

892

893

894

895

896

897

898

899 quantities of the Earth. Astronomy \& Astrophysics 428(1). EDP Sciences: 261-285. DOI: 10.1051/0004-6361:20041335.

Lionello P (2012) The Climate of the Mediterranean Region From the Past to the Future. DOI: 10.1016/B978-0-12-416042-2.00009-4.

Liquete C, Arnau P, Canals M, et al. (2005) Mediterranean river systems of Andalusia, southern Spain, and associated deltas: A source to sink approach. Marine Geology 222-223(1-4): 471495. DOI: 10.1016/j.margeo.2005.06.033.

Lirer F, Sprovieri M, Ferraro L, et al. (2013) Integrated stratigraphy for the Late Quaternary in the eastern Tyrrhenian Sea. Quaternary International 292. Pergamon: 71-85. DOI: 10.1016/J.QUAINT.2012.08.2055.

Lobo FJ, Fernández-Salas LM, Moreno I, et al. (2006) The sea-floor morphology of a Mediterranean shelf fed by small rivers, northern Alboran Sea margin. Continental Shelf Research 26(20). Pergamon: 2607-2628. DOI: 10.1016/j.csr.2006.08.006.

Locarnini RA, Mishonov A V., Antonov JI, et al. (2013) World ocean atlas 2013. Volume 1, Temperature. DOI: 10.7289/V55X26VD.

Lomb NR (1976) Least-square frequency analysis of unequally spaced data. Astrophys. Space Sci. 29: 447-462.

Lowe JJ, Rasmussen SO, Björck S, et al. (2008) Synchronisation of palaeoenvironmental events in the North Atlantic region during the Last Termination: a revised protocol recommended by the INTIMATE group. Quaternary Science Reviews 27(1-2): 6-17. DOI: 10.1016/j.quascirev.2007.09.016.

Magny M, Miramont C and Sivan O (2002) Assessment of the impact of climate and anthropogenic factors on Holocene Mediterranean vegetation in Europe on the basis of palaeohydrological records. Palaeogeography, Palaeoclimatology, Palaeoecology 186(1-2). Elsevier: 47-59. DOI: 10.1016/S0031-0182(02)00442-X.

Magny M, Combourieu-Nebout N, De Beaulieu JL, et al. (2013) North-south palaeohydrological contrasts in the central mediterranean during the holocene: Tentative synthesis and working 

hypotheses. Climate of the Past 9(5): 2043-2071. DOI: 10.5194/cp-9-2043-2013.

901

902

903

904

905

906

907

908

909

910

911

912

913

914

915

916

917

918

919

920

921

922

923

924

925

926

927

928

Margaritelli G, Vallefuoco M, Di Rita F, et al. (2016) Marine response to climate changes during the last five millennia in the central Mediterranean Sea. Global and Planetary Change 142. Elsevier: 53-72. DOI: 10.1016/J.GLOPLACHA.2016.04.007.

Marino M, Maiorano P, Tarantino F, et al. (2014) Coccolithophores as proxy of seawater changes at orbital-to-millennial scale during middle Pleistocene Marine Isotope Stages 14-9 in North Atlantic core MD01-2446. Paleoceanography 29(6). John Wiley \& Sons, Ltd: 518-532. DOI: 10.1002/2013PA002574.

Martrat B, Grimalt JO, Lopez-Martinez C, et al. (2004) Abrupt temperature changes in the Western Mediterranean over the past 250,000 years. Science (New York, N.Y.) 306(5702). American Association for the Advancement of Science: 1762-5. DOI: 10.1126/science.1101706.

Martrat B, Jimenez-Amat P, Zahn R, et al. (2014) Similarities and dissimilarities between the last two deglaciations and interglaciations in the North Atlantic region. Quaternary Science Reviews 99(October 2016): 122-134. DOI: 10.1016/j.quascirev.2014.06.016.

Mayewski PA, Rohling EJ, Stager CJ, et al. (2004) Holocene climate variability. Quaternary Research 62: 243-255. DOI: 10.1016/j.yqres.2004.07.001.

Meijer PT and Tuenter E (2007) The effect of precession-induced changes in the Mediterranean freshwater budget on circulation at shallow and intermediate depth. Journal of Marine Systems 68(3-4). Elsevier: 349-365. DOI: 10.1016/J.JMARSYS.2007.01.006.

Mertens C and Schott F (1998) Interannual Variability of Deep-Water Formation in the Northwestern Mediterranean. journal of physical oceanography 28: 1410-1428.

Millot C (2008) Short-term variability of the Mediterranean in- and out-flows. Geophysical Research Letters 35(15). John Wiley \& Sons, Ltd: L15603. DOI: 10.1029/2008GL033762.

Moreno A, Cacho I, Canals M, et al. (2004) Millennial-scale variability in the productivity signal from the Alboran Sea record, Western Mediterranean Sea. Palaeogeography, Palaeoclimatology, Palaeoecology 211(3-4). Elsevier: 205-219. DOI: 10.1016/J.PALAEO.2004.05.007.

Moreno A, Cacho I, Canals M, et al. (2005) Links between marine and atmospheric processes oscillating on a millennial time-scale. A multi-proxy study of the last 50,000 yr from the 
Alboran Sea (Western Mediterranean Sea). Quaternary Science Reviews 24(14-15): 16231636. DOI: 10.1016/j.quascirev.2004.06.018.

Moreno A, Pérez A, Frigola J, et al. (2012) The Medieval Climate Anomaly in the Iberian Peninsula reconstructed from marine and lake records. Quaternary Science Reviews 43. Elsevier Ltd: 16-32. DOI: 10.1016/j.quascirev.2012.04.007.

Moreno E, Thouveny N, Delanghe D, et al. (2002) Climatic and oceanographic changes in the Northeast Atlantic reflected by magnetic properties of sediments deposited on the Portuguese Margin during the last $340 \mathrm{ka}$. Earth and Planetary Science Letters 202(2). Elsevier: 465-480. DOI: 10.1016/S0012-821X(02)00787-2.

Munz PM, Siccha M, Lückge A, et al. (2015) Decadal-resolution record of winter monsoon intensity over the last two millennia from planktic foraminiferal assemblages in the northeastern Arabian Sea. Holocene 25(11). SAGE Publications Ltd: 1756-1771. DOI: $10.1177 / 0959683615591357$.

Nieto-Moreno V, Martínez-Ruiz F, Giralt S, et al. (2011) Tracking climate variability in the western Mediterranean during the Late Holocene: A multiproxy approach. Climate of the Past 7(4): 1395-1414. DOI: 10.5194/cp-7-1395-2011.

Nieto-Moreno V, Martinez-Ruiz F, Gallego-Torres D, et al. (2015) Palaeoclimate and palaeoceanographic conditions in the westernmost Mediterranean over the last millennium: an integrated organic and inorganic approach. Journal of the Geological Society 172(2): 264-271. DOI: 10.1144 /jgs2013-105.

Okada H and Wells P (1997) Late Quaternary nannofossil indicators of climate change in two deepsea cores associated with the Leeuwin Current off Western Australia. Palaeogeography, Palaeoclimatology, Palaeoecology 131(3-4). Elsevier: 413-432. DOI: 10.1016/S00310182(97)00014-X.

Olsen J, Anderson NJ and Knudsen MF (2012) Variability of the North Atlantic Oscillation over the past 5,200 years. Nature Geoscience 5(11): 808-812. DOI: 10.1038/ngeo1589.

Oviedo AM, Ziveri P and Gazeau F (2017) Coccolithophore community response to increasing pCO2 in Mediterranean oligotrophic waters. Estuarine, Coastal and Shelf Science 186: 58-71. DOI: 10.1016/j.ecss.2015.12.007. 
Pérez-Folgado M, Sierro FJ, Flores JA, et al. (2003) Western Mediterranean planktonic foraminifera events and millennial climatic variability during the last $70 \mathrm{kyr}$. Marine Micropaleontology 48(1-2). Elsevier: 49-70. DOI: 10.1016/S0377-8398(02)00160-3.

Pérez-Folgado M, Sierro FJ, Flores JA, et al. (2004) Paleoclimatic variations in foraminifer assemblages from the Alboran Sea (Western Mediterranean) during the last $150 \mathrm{ka}$ in ODP Site 977. Marine Geology 212(1-4): 113-131. DOI: 10.1016/j.margeo.2004.08.002.

Perkins H, Kinder T and La Violette PE (1990) The Atlantic Inflow in the Western Alboran Sea. Journal of Physical Oceanography 20: 242-263.

Peyron O, Combourieu-Nebout N, Brayshaw D, et al. (2017) Precipitation changes in the Mediterranean basin during the Holocene from terrestrial and marine pollen records: A modeldata comparison. Climate of the Past 13(3): 249-265. DOI: 10.5194/cp-13-249-2017.

Pflaumann U, Duprat J, Pujol C, et al. (1996) SIMMAX: A modern analog technique to deduce Atlantic sea surface temperatures from planktonic foraminifera in deep-sea sediments. Paleoceanography 11(1). John Wiley \& Sons, Ltd: 15-35. DOI: 10.1029/95PA01743.

Piva A, Asioli A, Andersen N, et al. (2008) Climatic cycles as expressed in sediments of the PROMESS1 borehole PRAD1-2, central Adriatic, for the last $370 \mathrm{ka}$ : 2. Paleoenvironmental evolution. Geochemistry, Geophysics, Geosystems 9(3). John Wiley \& Sons, Ltd: n/a-n/a. DOI: 10.1029/2007GC001785.

Principato MS, Crudeli D, Ziveri P, et al. (2006) Phyto_and zooplankton paleofluxes during the deposition of sapropel S1 (eastern Mediterranean): Biogenic carbonate preservation and paleoecological implications. Palaeogeography, Palaeoclimatology, Palaeoecology 235(1-3). Elsevier: 8-27. DOI: 10.1016/J.PALAEO.2005.09.021.

Pujol C and Vergnaud-Grazzini C (1995) Distribution patterns of live planktic foraminifers as related to regional hydrography and productive systems of the Mediterranean Sea. Marine Micropaleontology 25(2-3). Elsevier: 187-217. DOI: 10.1016/0377-8398(95)00002-I.

Ramos-Román MJ, Jiménez-Moreno G, Camuera J, et al. (2018) Millennial-scale cyclical environment and climate variability during the Holocene in the western Mediterranean region deduced from a new multi-proxy analysis from the Padul record (Sierra Nevada, Spain). Global and Planetary Change 168(June). Elsevier: 35-53. DOI: 10.1016/j.gloplacha.2018.06.003. 
Rasmussen SO, Andersen KK, Svensson AM, et al. (2006) A new Greenland ice core chronology for the last glacial termination. Journal of Geophysical Research Atmospheres 111(6): 1-16. DOI: $10.1029 / 2005 J D 006079$.

Repschläger J, Garbe-Schönberg D, Weinelt M, et al. (2017) Holocene evolution of the North Atlantic subsurface transport. Climate of the Past 13(4): 333-344. DOI: 10.5194/cp-13-3332017.

Rigual-Hernández AS, Sierro FJ, Bárcena MA, et al. (2012) Seasonal and interannual changes of planktic foraminiferal fluxes in the Gulf of Lions (NW Mediterranean) and their implications for paleoceanographic studies: Two 12-year sediment trap records. Deep Sea Research Part I: Oceanographic Research Papers 66. Pergamon: 26-40. DOI: 10.1016/J.DSR.2012.03.011.

Rixen M, Beckers JM, Levitus S, et al. (2005) The Western Mediterranean Deep Water: A proxy for climate change. Geophysical Research Letters 32(12): 1-4. DOI: 10.1029/2005GL022702.

Rodrigo-Gámiz M, Martínez-Ruiz F, Jiménez-Espejo FJ, et al. (2011) Impact of climate variability in the western Mediterranean during the last 20,000 years: Oceanic and atmospheric responses. Quaternary Science Reviews 30(15-16). Elsevier Ltd: 2018-2034. DOI: 10.1016/j.quascirev.2011.05.011.

Rogerson M, Cacho I, Jimenez-Espejo FJ, et al. (2008) A dynamic explanation for the origin of the western Mediterranean organic-rich layers. Geochemistry, Geophysics, Geosystems 9(7). John Wiley \& Sons, Ltd: n/a-n/a. DOI: 10.1029/2007GC001936.

Rohling EJ and Pälike H (2005) Centennial-scale climate cooling with a sudden cold event around 8,200 years ago. Nature 434(7036): 975-979. DOI: 10.1038/nature03421.

Rohling EJ, Den Dulk M, Pujol C, et al. (1995) Abrupt hydrographic change in the Alboran Sea (western Mediterranean) around 8000 yrs BP. Deep-Sea Research Part I 42(9): 1609-1619. DOI: 10.1016/0967-0637(95)00069-I.

Rohling EJ, Jorissen FJ and De Stigter HC (1997) 200 Year interruption of Holocene sapropel formation in the Adriatic Sea. Journal of Micropalaeontology 16(2): 97-108. DOI: 10.1144/jm.16.2.97.

Rohling EJ, Cane TR, Cooke S, et al. (2002) African monsoon variability during the previous interglacial maximum. Earth and Planetary Science Letters 202(1). Elsevier: 61-75. DOI: 
Rohling EJ, Sprovieri M, Cane T, et al. (2004) Reconstructing past planktic foraminiferal habitats using stable isotope data: a case history for Mediterranean sapropel S5. Marine Micropaleontology 50(1-2). Elsevier: 89-123. DOI: 10.1016/S0377-8398(03)00068-9.

1021 1022 1023 1024 1025 1026

Rohling EJ, Marino G and Grant KM (2015) Mediterranean climate and oceanography, and the periodic development of anoxic events (sapropels). Earth-Science Reviews 143. Elsevier B.V.: 62-97. DOI: 10.1016/j.earscirev.2015.01.008.

Rossignol-Strick M (1985) Mediterranean Quaternary sapropels, an immediate response of the African monsoon to variation of insolation. Palaeogeography, Palaeoclimatology, Palaeoecology 49(3-4). Elsevier: 237-263. DOI: 10.1016/0031-0182(85)90056-2.

Rossignol-Strick M, Nesteroff W, Olive P, et al. (1982) After the deluge: Mediterranean stagnation and sapropel formation. Nature 295(5845). Nature Publishing Group: 105-110. DOI: 10.1038/295105a0.

Salgueiro E, Voelker AHL, de Abreu L, et al. (2010) Temperature and productivity changes off the western Iberian margin during the last $150 \mathrm{ky}$. Quaternary Science Reviews 29(5-6). Pergamon: 680-695. DOI: 10.1016/J.QUASCIREV.2009.11.013.

Salgueiro E, Naughton F, Voelker AHL, et al. (2014) Past circulation along the western Iberian margin: A time slice vision from the Last Glacial to the Holocene. Quaternary Science Reviews 106: 316-329. DOI: 10.1016/j.quascirev.2014.09.001.

Sarhan T, García-Lafuente J, Vargas M, et al. (2000) Upwelling mechanisms in the northwestern Alboran Sea. Journal of Marine Systems 23(4): 317-331. DOI: 10.1016/S09247963(99)00068-8.

Sbaffi L, Wezel FC, Kallel N, et al. (2001) Response of the pelagic environment to palaeoclimatic changes in the central Mediterranean Sea during the Late Quaternary. Marine Geology 178(14): 39-62. DOI: 10.1016/S0025-3227(01)00185-2.

Scargle JD (1982) Studies in astronomical time series analysis, II Statistical aspects of spectral analysis of unevenly spaced data. Astrophys. J. 263: 835-853.

Schiebel R, Waniek J, Bork M, et al. (2001) Planktic foraminiferal production stimulated by chlorophyll redistribution and entrainment of nutrients. Deep Sea Research Part I: 
Oceanographic Research Papers 48(3). Pergamon: 721-740. DOI: 10.1016/S09670637(00)00065-0.

Schirrmacher J, Weinelt M, Blanz T, et al. (2019) Multi-decadal climate variability in southern Iberia during the mid- to late-Holocene. Climate of the Past Discussions: 1-29. DOI: $10.5194 / \mathrm{cp}-2018-158$.

Schulz M and Mudelsee M (2002) REDFIT: estimating red-noise spectra directly from unevenly spaced paleoclimatic time series. Comput. Geosci. 28: 421-426.

Siccha M, Trommer G, Schulz H, et al. (2009) Factors controlling the distribution of planktonic foraminifera in the Red Sea and implications for the development of transfer functions. Marine Micropaleontology 72(3-4). Elsevier: 146-156. DOI: 10.1016/J.MARMICRO.2009.04.002.

Sierro FJ, Hodell DA, Curtis JH, et al. (2005) Impact of iceberg melting on Mediterranean thermohaline circulation during Heinrich events. Paleoceanography 20(2): 1-13. DOI: 10.1029/2004PA001051.

Smith AC, Wynn PM, Barker PA, et al. (2016) North Atlantic forcing of moisture delivery to Europe throughout the Holocene. Scientific Reports 6. Nature Publishing Group: 1-7. DOI: 10.1038/srep24745.

Smith RO, Bryden HL and Stansfield K (2008) Observations of new western Mediterranean deep water formation using Argo floats. Ocean Sci.

Spezzaferri S, Kucera M, Pearson PN, et al. (2015) Fossil and Genetic Evidence for the Polyphyletic Nature of the Planktonic Foraminifera 'Globigerinoides', and Description of the New Genus Trilobatus. Abramovich S (ed.) PLOS ONE 10(5). Public Library of Science. DOI: 10.1371/journal.pone.0128108.

Sprovieri M, Di Stefano E, Incarbona A, et al. (2012) Centennial- to millennial-scale climate oscillations in the Central-Eastern Mediterranean Sea between 20,000 and 70,000 years ago: Evidence from a high-resolution geochemical and micropaleontological record. Quaternary Science Reviews 46: 126-135. DOI: 10.1016/j.quascirev.2012.05.005.

Sprovieri R, Di Stefano E, Incarbona A, et al. (2003) A high-resolution record of the last deglaciation in the Sicily Channel based on foraminifera and calcareous nannofossil quantitative distribution. Palaeogeography, Palaeoclimatology, Palaeoecology 202(1-2): 119- 
Steinmetz JC (1994) Sedimentation of Coccolithophores. In: Coccolithophores, pp. 179-183.

Stolz K and Baumann K-H (2010) Changes in palaeoceanography and palaeoecology during Marine Isotope Stage (MIS) 5 in the eastern North Atlantic (ODP Site 980) deduced from calcareous nannoplankton observations. Palaeogeography, Palaeoclimatology, Palaeoecology 292(1-2). Elsevier B.V.: 295-305. DOI: 10.1016/j.palaeo.2010.04.002.

Sumner G, Homar V and Ramis C (2001) Precipitation seasonality in eastern and southern coastal Spain. International Journal of Climatology 21(2). John Wiley \& Sons, Ltd: 219-247. DOI: 10.1002/joc. 600 .

Takahashi K and Okada H (2000) Environmental control on the biogeography of modern coccolithophores in the southeastern Indian Ocean offshore of Western Australia. Marine Micropaleontology 39(1-4): 73-86. DOI: 10.1016/S0377-8398(00)00015-3.

Thornalley DJR, Elderfield H and McCave N (2009) Holocene oscillations in temperature and salinity of the surface subpolar North Atlantic. Nature 457. Nature Publishing Group: 711713. DOI: $10.1038 /$ nature07717.

Toucanne S, Zaragosi S, Bourillet J-F, et al. (2012) External controls on turbidite sedimentation on the glacially-influenced Armorican margin (Bay of Biscay, western European margin). Marine Geology 303-306. Elsevier: 137-153. DOI: 10.1016/J.MARGEO.2012.02.008.

Toucanne S, Angue Minto'o CM, Fontanier C, et al. (2015) Tracking rainfall in the northern Mediterranean borderlands during sapropel deposition. Quaternary Science Reviews 129. Pergamon: 178-195. DOI: 10.1016/J.QUASCIREV.2015.10.016.

Triantaphyllou M, Antonarakou A, Dimiza M, et al. (2010) Calcareous nannofossil and planktonic foraminiferal distributional patterns during deposition of sapropels S6, S5 and S1 in the Libyan Sea (Eastern Mediterranean). Geo-Marine Letters 30(1): 1-13. DOI: 10.1007/s00367-0090145-7.

Trigo R, Pozo-Vázquez D, Osborn TJ, et al. (2004) North Atlantic oscillation influence on precipitation, river flow and water resources in the Iberian Peninsula. International Journal of Climatology 24(8): 925-944. DOI: 10.1002/joc.1048. 
Vallefuoco M, Lirer F, Ferraro L, et al. (2012) Climatic variability and anthropogenic signatures in the Gulf of Salerno (southern-eastern Tyrrhenian Sea) during the last half millennium. Rendiconti Lincei 23(1). Springer Milan: 13-23. DOI: 10.1007/s12210-011-0154-0.

Vargas-Yáñez M, Jesús García M, Salat J, et al. (2008) Warming trends and decadal variability in the Western Mediterranean shelf. Global and Planetary Change 63(2-3). Elsevier: 177-184. DOI: 10.1016/J.GLOPLACHA.2007.09.001.

Vincent E and Berger WH (1981) Planktonic foraminifera and their use in paleoceanography. The Sea 7: 371-412.

Viúdez Á, Tintoré J, Haney RL, et al. (1996) Circulation in the Alboran Sea as Determined by Quasi-Synoptic Hydrographic Observations. Part I: Three-Dimensional Structure of the Two Anticyclonic Gyres. Journal of Physical Oceanography 26(5): 684-705. DOI: 10.1175/15200485(1996)026<0684:CITASA>2.0.CO;2.

Walker MJC, Berkelhammer M, Björck S, et al. (2012) Formal subdivision of the Holocene Series/Epoch: A Discussion Paper by a Working Group of INTIMATE (Integration of icecore, marine and terrestrial records) and the Subcommission on Quaternary Stratigraphy (International Commission on Stratigraphy). Journal of Quaternary Science 27(7): 649-659. DOI: $10.1002 /$ jqs.2565.

Wanner H, Mercolli L, Grosjean M, et al. (2015) Holocene climate variability and change; a databased review. Journal of the Geological Society 172(2): 254-263. DOI: 10.1144/jgs2013-101.

Weaver PPE and Pujol C (1988) History of the last deglaciation in the alboran sea (western Mediterranean) and adjacent north Atlantic as revealed by coccolith floras. Palaeogeography, Palaeoclimatology, Palaeoecology 64(1-2): 35-42. DOI: 10.1016/0031-0182(88)90140-X.

Winter A and Siesser WG (1994) Coccolithophores. Cambridge University Press.

Young J, Geisen M, Cros L, et al. (2003) A guide to extant coccolithophore taxonomy. Journal of Nannoplankton Research Special Issue 1.

Zachariasse W-J, Jorissen FJ, Perissoratis C, et al. (1997) Late Quaternary foraminiferal changes and the nature of Sapropel S1 in Skopelos Basin. Proceeding of the 5th Hellenic Symposium 
on Oceanography and Fisheries 1: 391-394.

Zanchetta G, Drysdale RN, Hellstrom JC, et al. (2007) Enhanced rainfall in the Western Mediterranean during deposition of sapropel S1: stalagmite evidence from Corchia cave (Central Italy). Quaternary Science Reviews 26(3-4): 279-286. DOI: 10.1016/j.quascirev.2006.12.003.

Zielhofer C, Fletcher WJ, Mischke S, et al. (2017) Atlantic forcing of Western Mediterranean winter rain minima during the last 12,000 years. Quaternary Science Reviews 157. Elsevier Ltd: 29-51. DOI: 10.1016/j.quascirev.2016.11.037.

\section{Figure captions}

Fig. 1: Location of ODP Site 976 in the Alboran Sea (western Mediterranean), bathymetry of the area and modern-day oceanographic circulation. AW (Atlantic Water); MOW (Mediterranean Outflow Water); WMDW (western Mediterranean Deep Water); LIW (Levantine Intermediate Water); WAG (western Alboran Gyre); EAG (eastern Alboran Gyre). In violet shade: Alboran and Almeria-Oran upwelling fronts

Fig. 2: Downcore variations of calcareous nannofossil assemblages at Site 976 plotted as relative abundance (\%, black line) and nannofossil accumulation rate - NAR (coccolith/ $\mathrm{cm}^{2} \mathrm{kyr}$, filled area). Sedimentation rate over time used for NAR calculation, from Martrat et al. (2014), is also shown. YD: Younger Dryas.

Fig. 3: Downcore variations of planktonic foraminifera assemblages at Site 976 plotted as relative abundance (\%, black line) and planktonic foraminifera accumulation rate - pfAR (forams $/ \mathrm{cm}^{2} \mathrm{kyr}$, filled area), together with foraminifera-based summer, winter and annual SST and similarity index. Sedimentation rate over time, used for pfAR calculation, from Martrat et al. (2014). YD: Younger Dryas.

Fig. 4:(a) Signal of the Total NAR decomposed with CEEMD in five IMFs plus a residue (trend); (b), (c), (d), (e) spectral analysis made with "REDFIT" and Foster's WWZ, of the IMFs extracted from Total NAR. The green and black line represent the 95\% and 80\% Confident Level respectively. Significantly periodicity (red dot) and relative values expressed in years were 
reported.

Fig. 5: Abundances variations of calcareous plankton assemblage and additional proxies from Site 976: accumulation rate of selected coccolithophores and planktonic foraminifera; relative abundance patterns of selected pollen taxa at Site 976 from Combourieu-Nebout et al. (2009); black line, 3 point average. Di- and tri-unsaturated alkenones of 37 carbons $\left(\mathrm{C}_{37}\right)$ from Martrat et al. (2014) and summer insolation curve (Laskar et al., 2004) are also shown. Younger Dryas (YD, grey bar); 8.2 ka event (light blue bar); dashed black lines are used to trace boundaries among phases IIII.

Fig. 6: Abundances variations of calcareous plankton assemblage and additional proxies from Site 976: accumulation rate of selected coccolithophores and planktonic foraminifera; black line, 3 point average; foram based seasonal SST variations at Site 976; relative abundance patterns of selected pollen taxa at Site 976 from Combourieu-Nebout et al. (2009). 8.2 ka event (dotted bar), dashed black lines are used to trace boundaries among phases I-III.

Fig. 7: Abundances variation of coccolithophore assemblage and climate proxies from Site 976: $G$. oceanica absolute abundances (black line, 3 point average); $\delta^{18} \mathrm{O}_{\text {seawater }}$ at Site 976 (green line, 3 point average) (Jimenez-Amat and Zahn, 2015); $\delta^{18} \mathrm{O}$ of combined and de-trended speleothems from Iberian Peninsula (Smith et al., 2016); coccolithophore productivity (total Nannofossil Accumulation Rate) at Site 976 (black line, 3 point average). Inferred NAO circulation pattern from redox variability from Lake SS1220, Greenland (Olsen et al., 2012) is also shown. Light blue bars represent periods of increased total NAR concomitant with enhanced Atlantic inflow and positive NAO index phases.

Fig. 8: Proposed different NAO circulations pattern scenarios as explained in the text: a) NAO+ enhanced northwesterly winds, deep water formation and Atlantic inflow inducing upwelling and coccolithophore productivity; b) NAO- reduced northwesterly winds, deep water formation and Atlantic inflow, inducing stratification and reduced coccolithophore productivity. LIW (Levantine Intermediate Water). AJ (Atlantic Jet); WMDW (western Mediterranean Deep Water). MOW (Mediterranean Outflow Water). Diagram not to scale. 


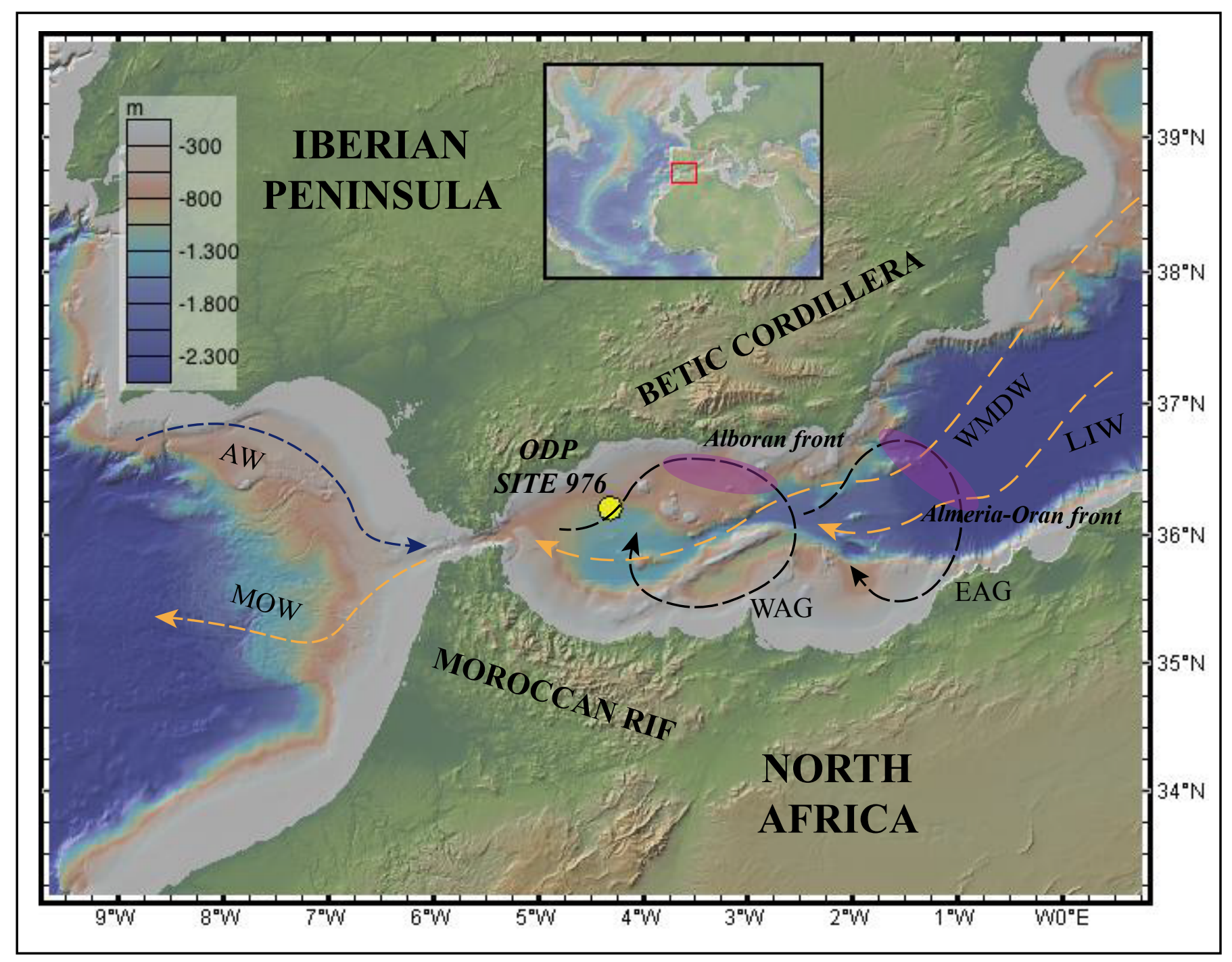




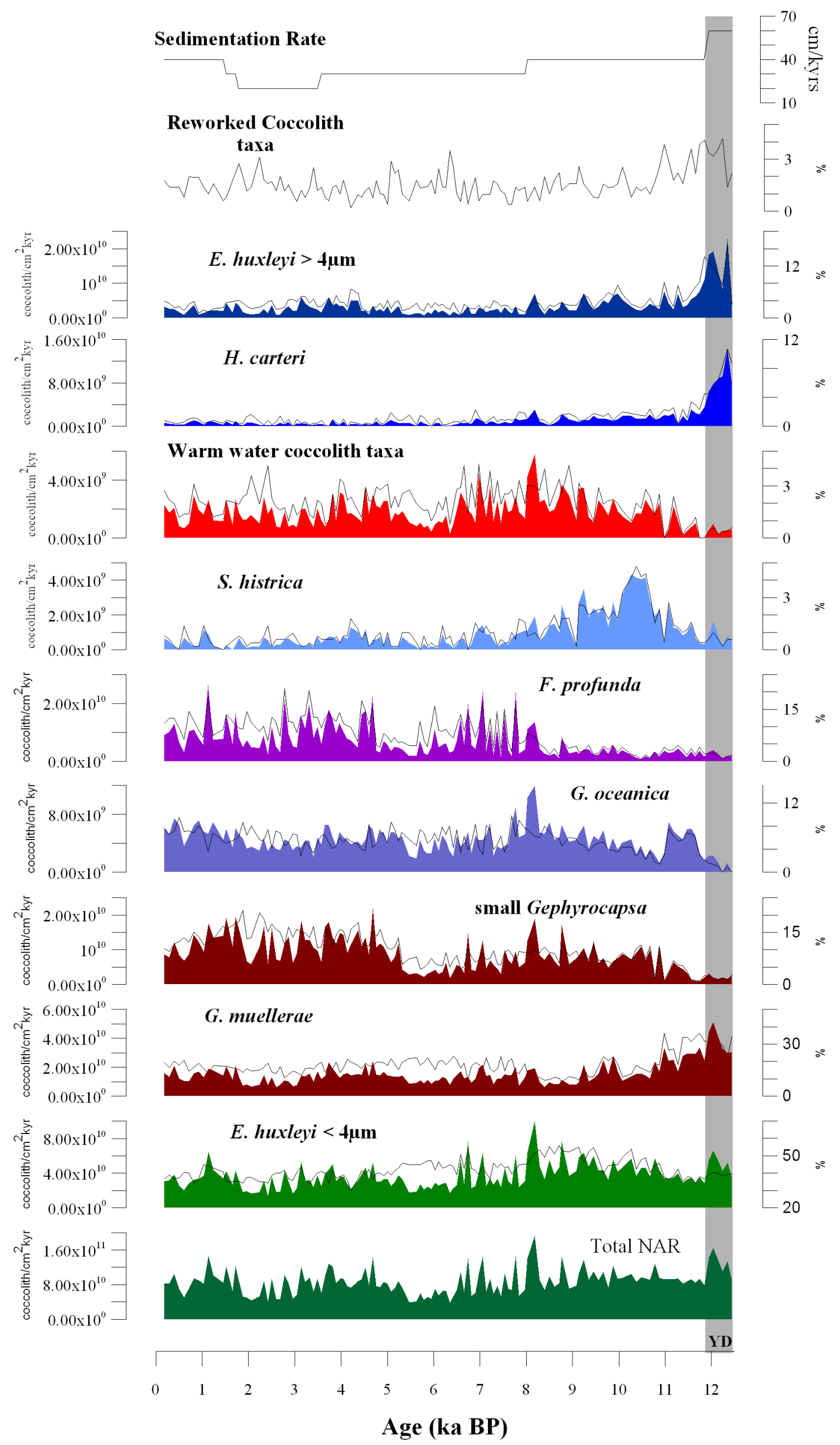




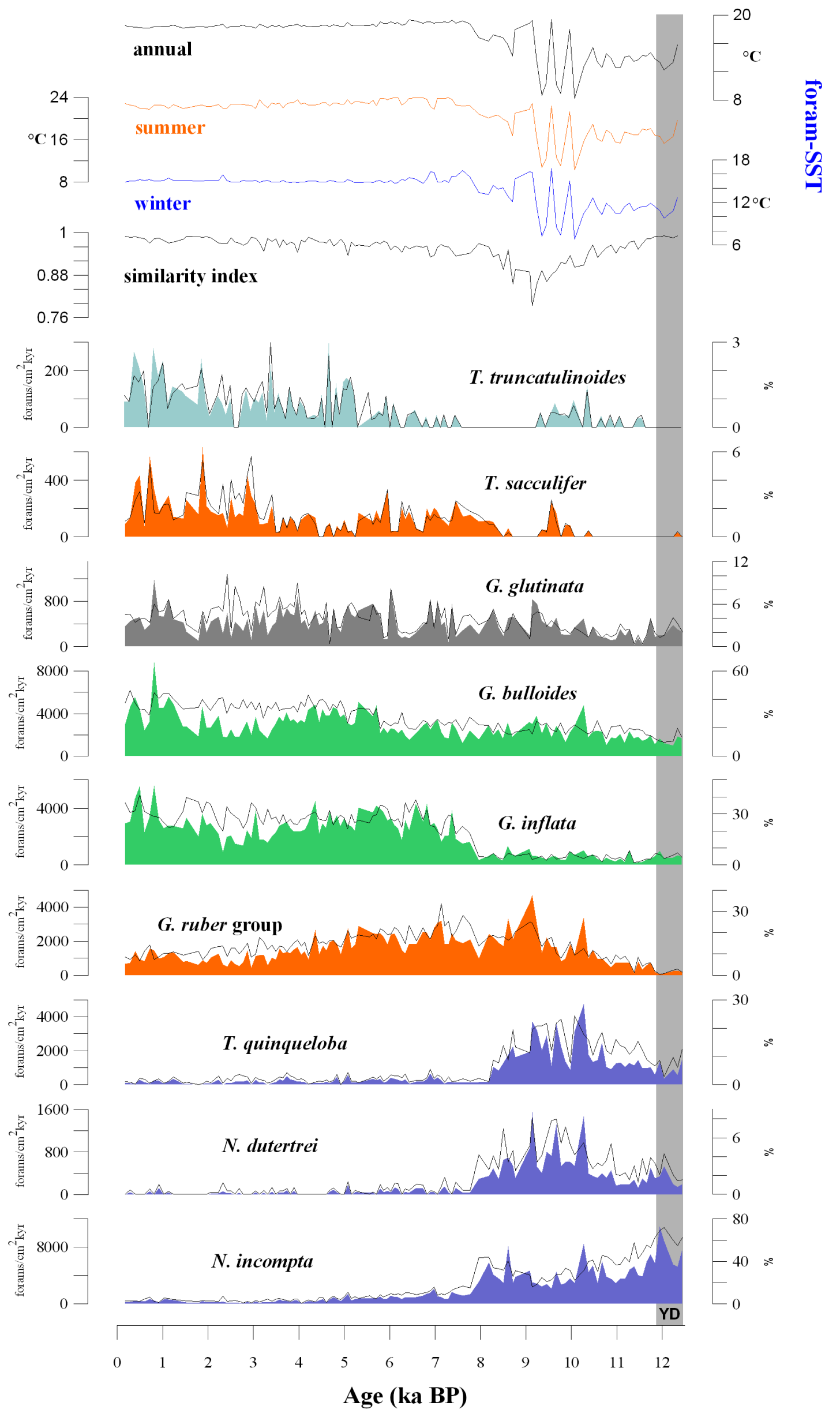




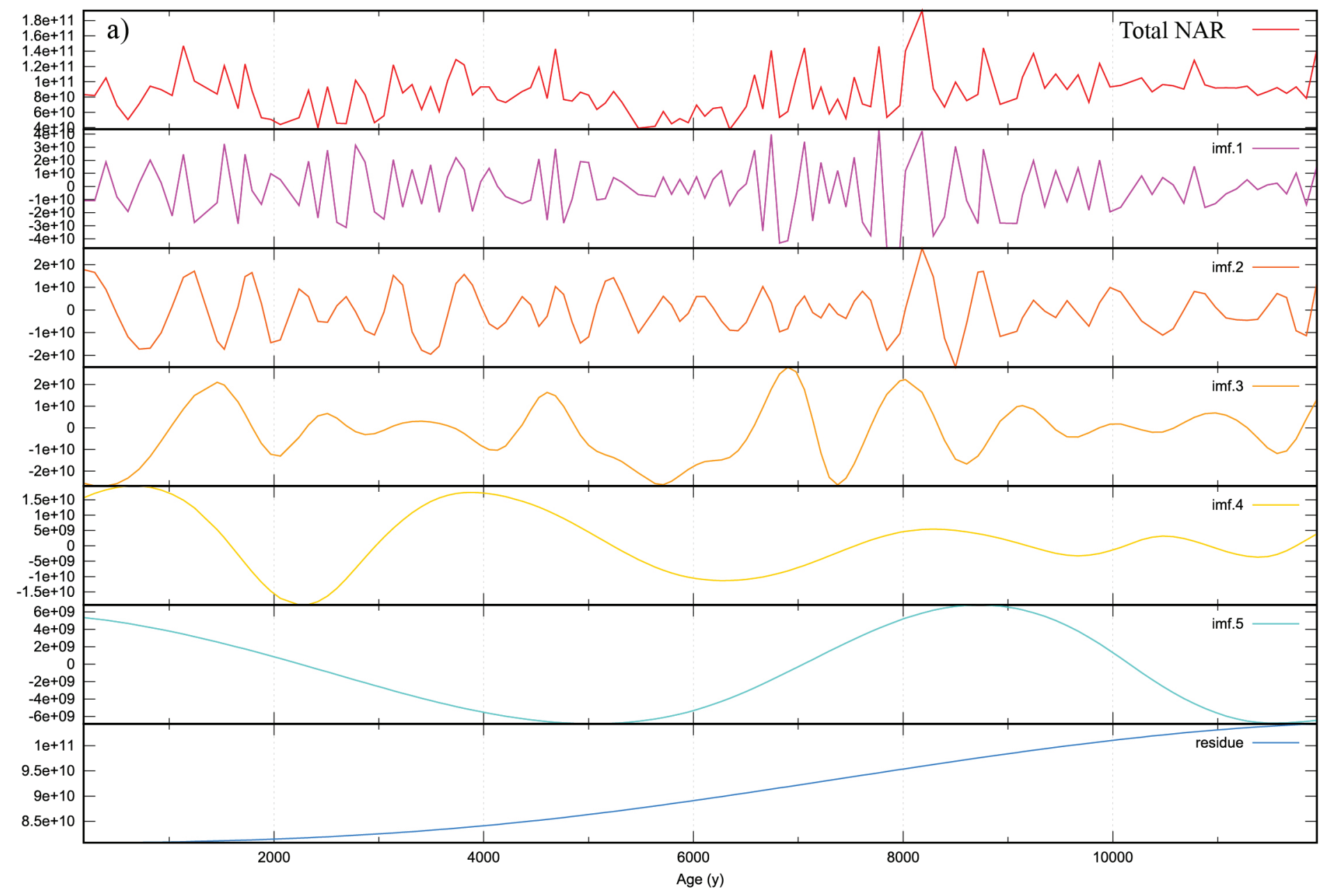

Total NAR IMF2

Total NAR IMF3
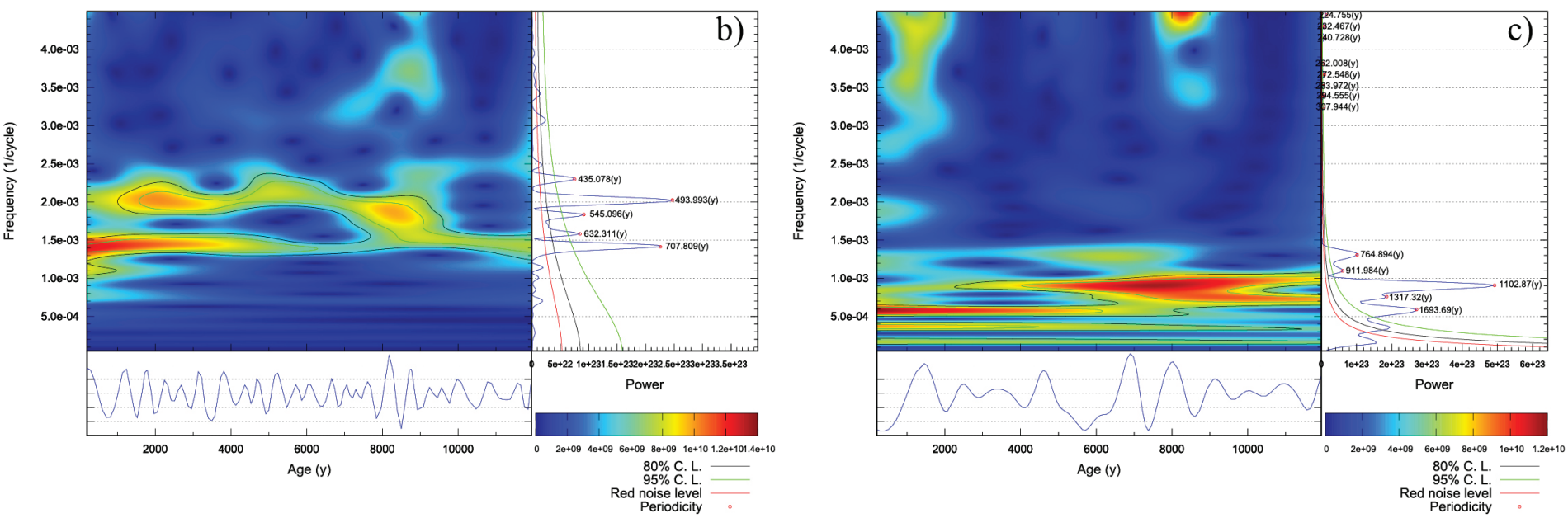

Total NAR IMF4

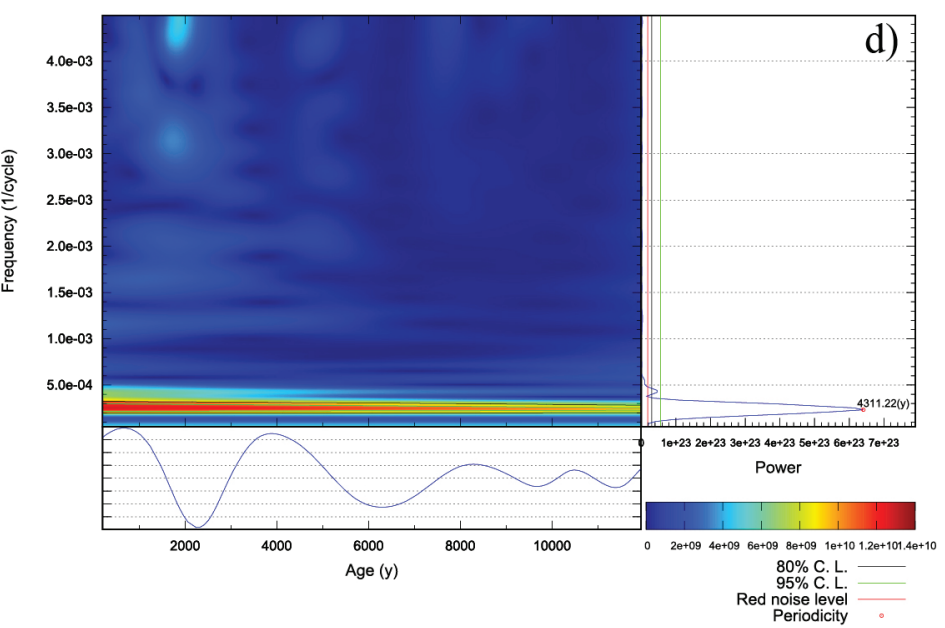

Total NAR IMF5

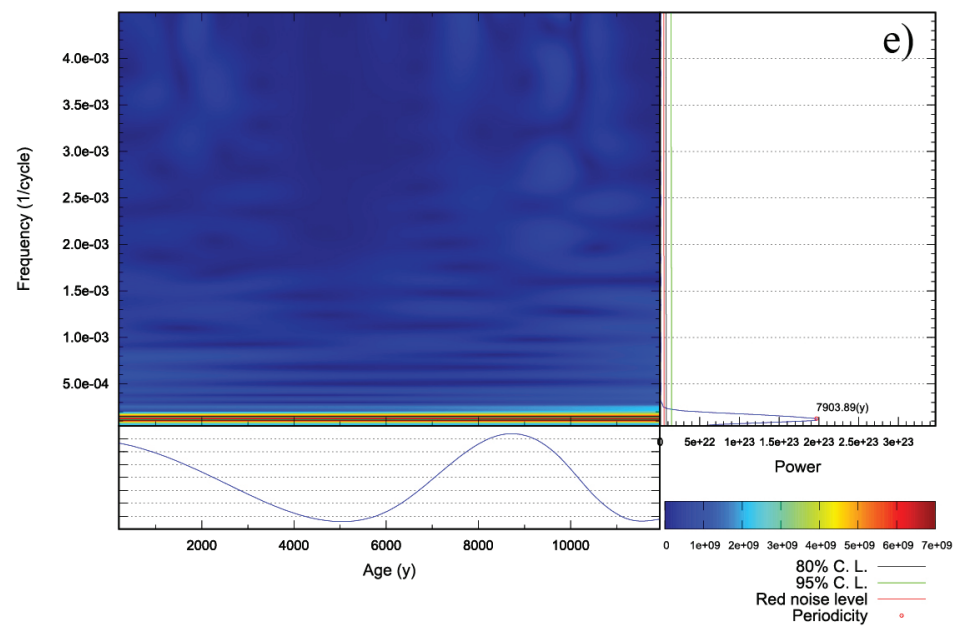




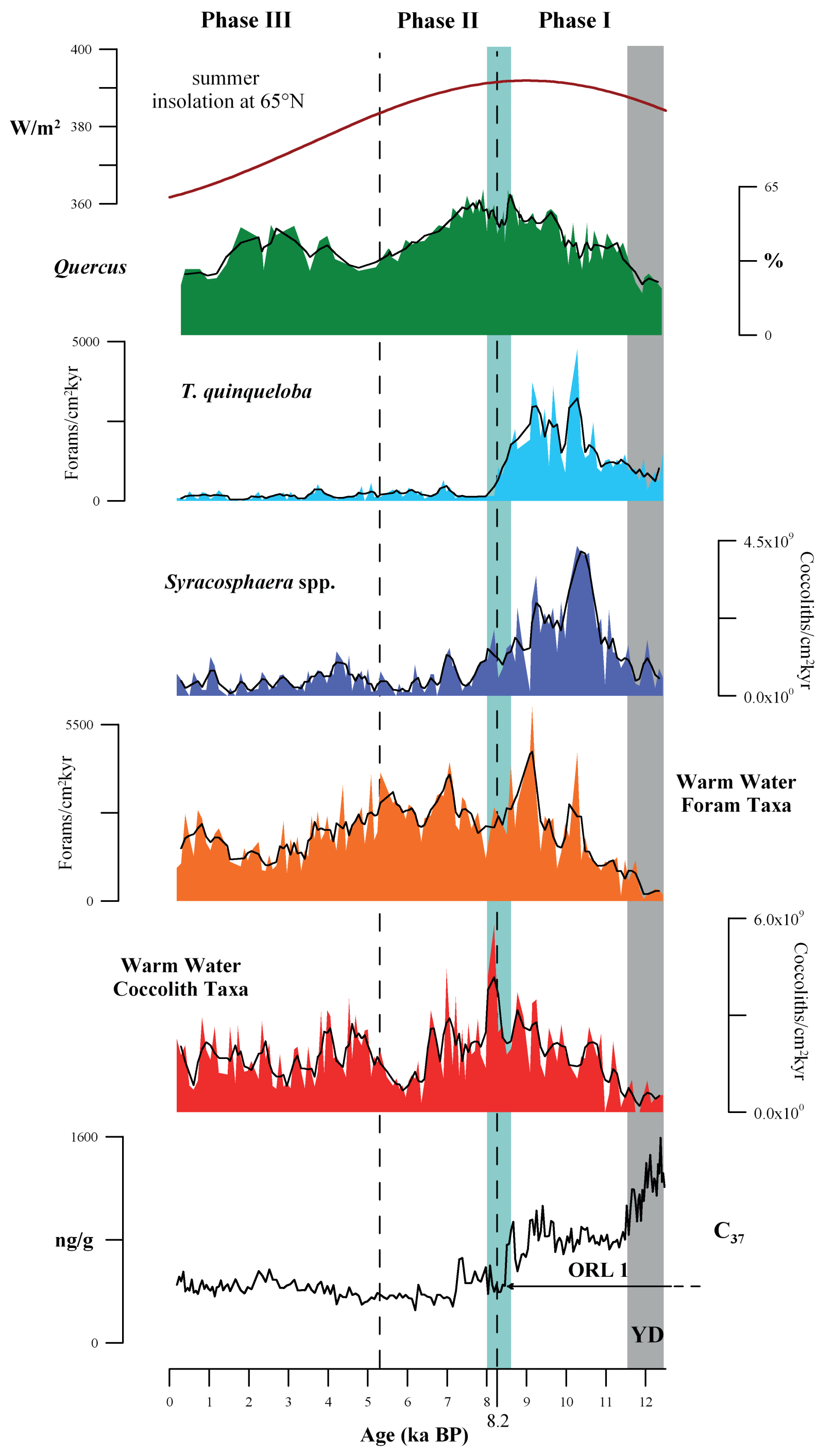


Phase III

Phase II

Phase I

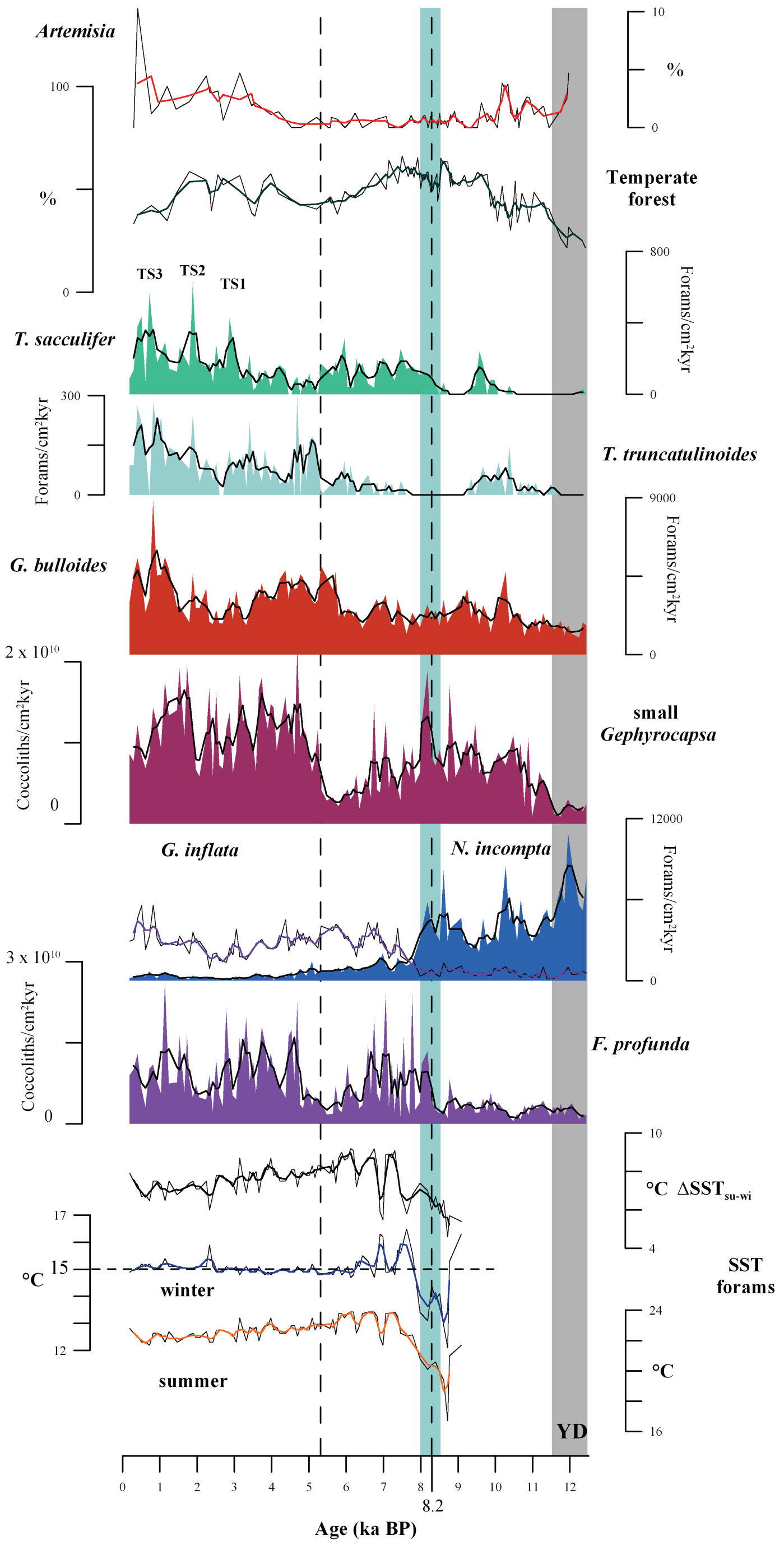




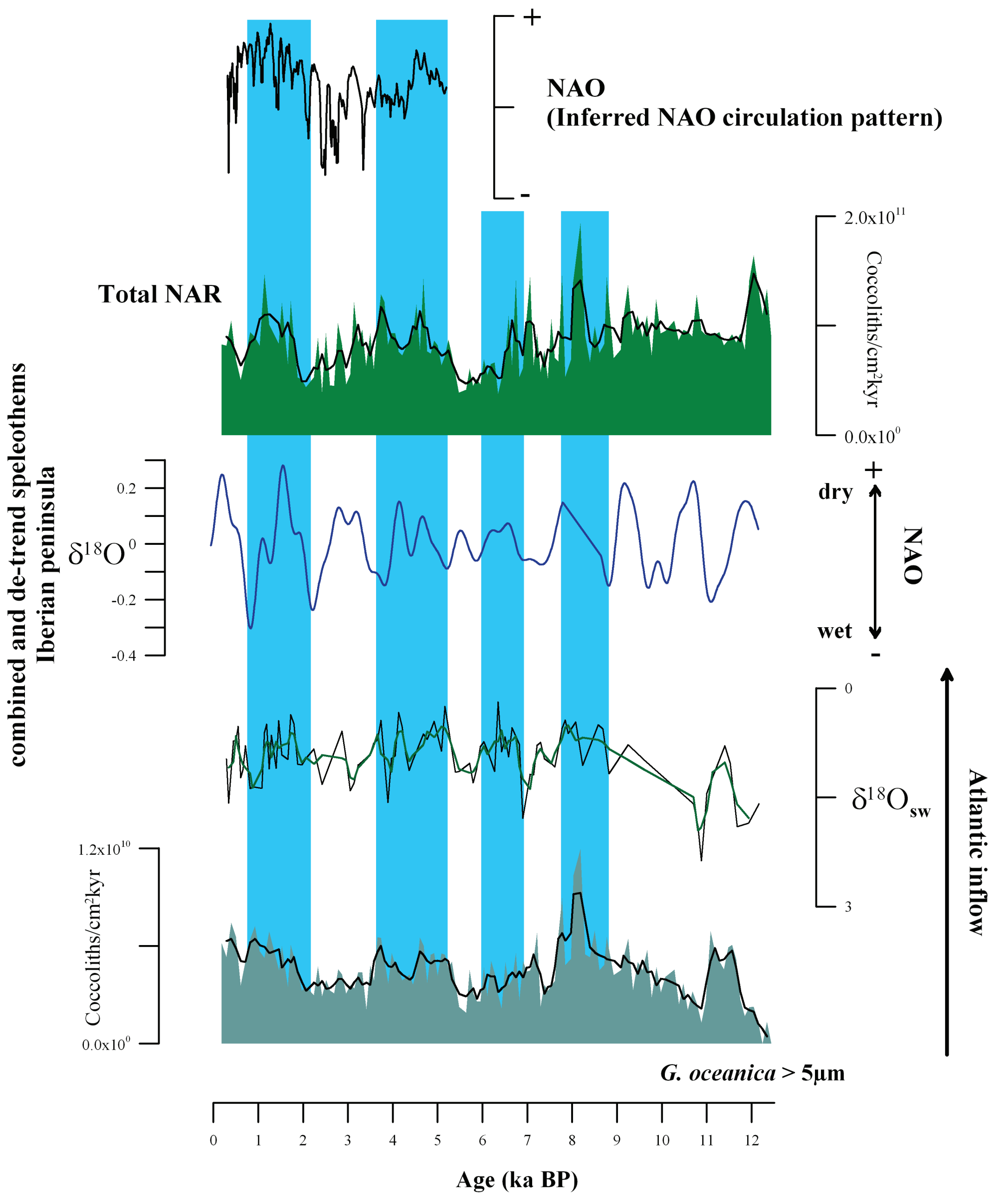




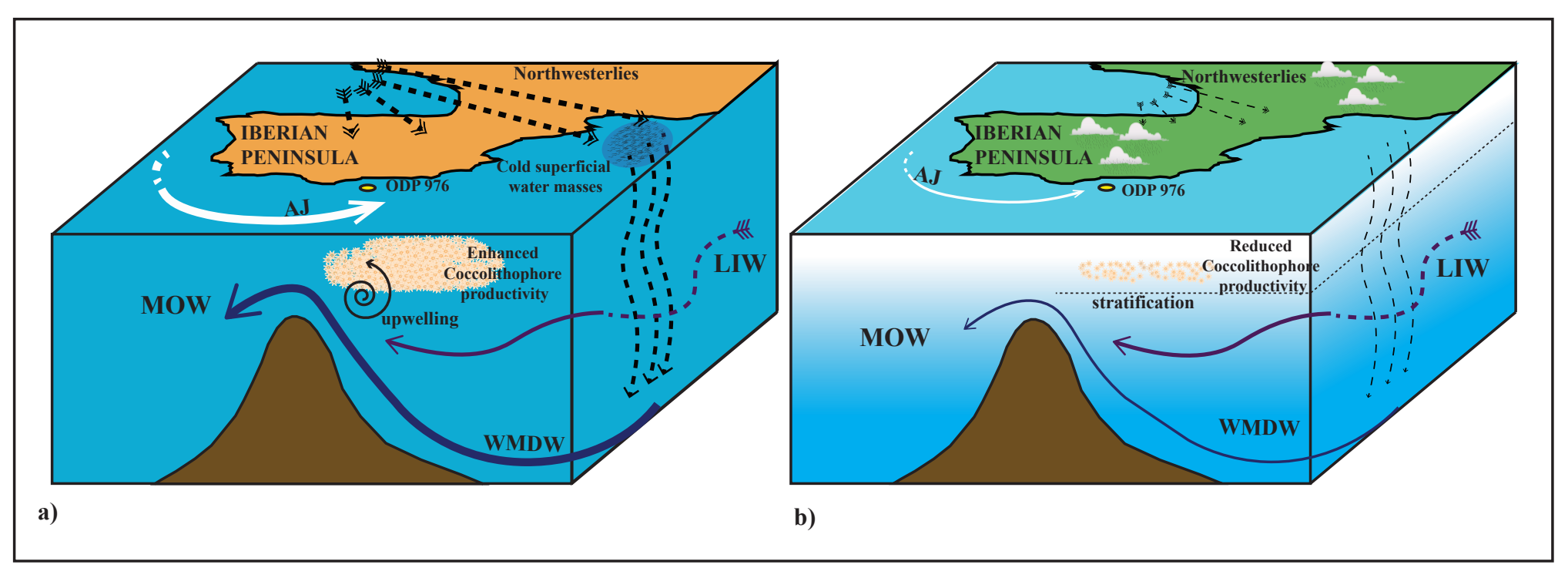

